\title{
Multifunctional Nanoscale Metal-Organic Layers for Ratiometric pH and Oxygen Sensing
}

Guangxu Lan, ${ }^{\ddagger}, 1$ Kaiyuan Ni, ${ }^{\ddagger}, 1$ Eric You, ${ }^{1}$ Maolin Wang,,${ }^{1,3}$ August Culbert, ${ }^{1}$ Xiaomin Jiang, ${ }^{1}$ and Wenbin Lin*,1,2

${ }^{1}$ Department of Chemistry and ${ }^{2}$ Department of Radiation and Cellular Oncology and Ludwig Center for Metastasis Research, The University of Chicago, Chicago, Illinois 60637, United States

${ }^{3}$ College of Chemistry and Molecular Engineering, Peking University, Beijing 100871, China These authors contributed equally

E-mail: wenbinlin@uchicago.edu

\section{Table of Contents}

$\begin{array}{lr}\text { S1. Materials and Methods } & \text { S2 }\end{array}$

S2. Synthesis and Characterization of $\mathrm{Hf}_{12}-\mathrm{Ru}$ and $\mathrm{Hf}_{12}-\mathrm{Ru}-\mathrm{F} / \mathrm{R} \quad \mathrm{S3}$

S3. Luminescence Analysis $\quad$ S10

S4. In vitro $\mathrm{pH}$ and $\mathrm{O}_{2}$ sensing $\quad$ S23

$\begin{array}{lr}\text { S5. References } & \text { S27 }\end{array}$ 


\section{S1. Materials and Methods}

All starting materials were purchased from Sigma-Aldrich and Fisher (USA) unless otherwise noted and used without further purification. Transmission electron microscopy (TEM) was carried out on TECNAI Spirit and F30 HRTEM. Powder X-ray diffraction (PXRD) data was collected on a Bruker D8 Venture diffractometer using a $\mathrm{Cu} \mathrm{K} \alpha$ radiation source $(1=1.54178 \AA)$. Atomic force microscopy $(\mathrm{AFM})$ images were taken on a Bruker $\mathrm{V}$ /Multimode 8 instrument. Inductively coupled plasma-mass spectrometry (ICP-MS) data was obtained with an Agilent 7700x ICP-MS and analyzed using ICP-MS Mass Hunter version B01.03. Samples were diluted in a $2 \% \mathrm{HNO}_{3}$ matrix and analyzed with a ${ }^{159} \mathrm{~Tb}$ internal standard against a 12-point standard curve over the range from $0.1 \mathrm{ppb}$ to $500 \mathrm{ppb}$. The correlation was >0.9997 for all analyses of interest. Data collection was performed in Spectrum Mode with five replicates per sample and 100 sweeps per replicate. ${ }^{1} \mathrm{H}$ NMR spectra were recorded on a Bruker NMR 500 DRX spectrometer at $500 \mathrm{MHz}$ and referenced to the proton resonance resulting from incomplete deuteration of $\mathrm{CDCl}_{3}$ or in DMSO-d6. High-resolution mass spectra were recorded on an Agilent 6540 Q-Tof MS-MS. Thermogravimetric analysis (TGA) was performed in air using a Shimadzu TGA-50 equipped with a platinum pan and heated at a rate of $1{ }^{\circ} \mathrm{C}$ per min. $\mathrm{pH}$ values of different PBS buffer solutions were determined with a Fisher Scientific accumet AB150 pH meter. $\mathrm{O}_{2}$ pressure in glove box was measured by a commercial oxygen sensor (YSI ProODO 626279). Luminescence data were measured using an RF-5301PC spectrofluorophotometer (Shimadzu, Japan) and a Xenogen IVIS 200 imaging system (Xenogen, USA). Confocal images were scanned by SP8 LIGHTNING confocal microscope (Leica, Germany). Images were processed and analyzed with ImageJ (NIH, USA).

Murine colon adenocarcinoma cell CT26 and MC38 were purchased from the American Type Culture Collection (Rockville, MD, USA). Cells were cultured in Roswell Park Memorial Institute (RPMI) 1640 medium (GE Healthcare, USA) supplemented with 10\% FBS, $100 \mathrm{U} / \mathrm{mL}$ penicillin $\mathrm{G}$ sodium and $100 \mu \mathrm{g} / \mathrm{mL}$ streptomycin sulfate in a humidified atmosphere containing $5 \% \mathrm{CO}_{2}$ at $37^{\circ} \mathrm{C}$. 


\section{S2. Synthesis and Characterization of $\mathrm{Hf}_{12}-\mathrm{Ru}$ and $\mathrm{Hf}_{12}-\mathrm{Ru}-\mathrm{F} / \mathrm{R}$}

\section{S2.1 Synthesis of $\mathrm{H}_{2}$ DBB-Ru ligands}
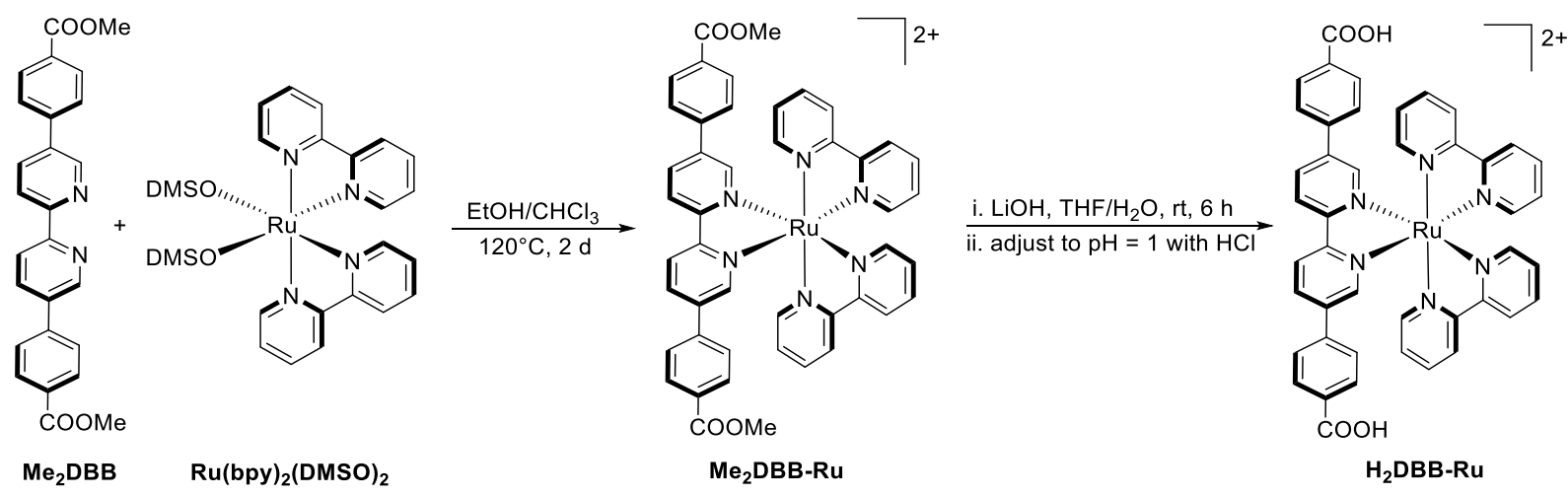

Figure S1. Synthesis route of $\mathrm{H}_{2} \mathrm{DBB}-\mathrm{Ru}$.

Synthesis of $\mathbf{H}_{2}$ DBB-Ru. $\mathrm{Ru}(\mathrm{DBB})(\mathrm{bpy}) 2^{2+}\left[\mathrm{H}_{2} \mathrm{DBB}-\mathrm{Ru}\right.$, bpy $=2$, $2^{\prime}$-bipyridine, $\mathrm{DBB}=$ 4,4'-di(4-benzoato)-2,2'-bipyridine] was synthesized as shown in Figure S1 according to the literature. ${ }^{1}{ }^{1} \mathrm{H}$ NMR (500 MHz, DMSO- $\left.d_{6}\right): \delta 9.05$ (d, $\left.2 \mathrm{H}\right), 8.88$ (d, $\left.2 \mathrm{H}\right), 8.85$ (d, $\left.2 \mathrm{H}\right), 8.59$ (d, 2 H), 8.23 (t, 2 H), 8.18 (t, 2 H), 8.00 (d, 4 H), 7.96 (d, 2 H), 7.85 (d, 2 H), $7.81(\mathrm{~s}, 2$ H), 7.64-7.55 (m, $8 \mathrm{H})$. 


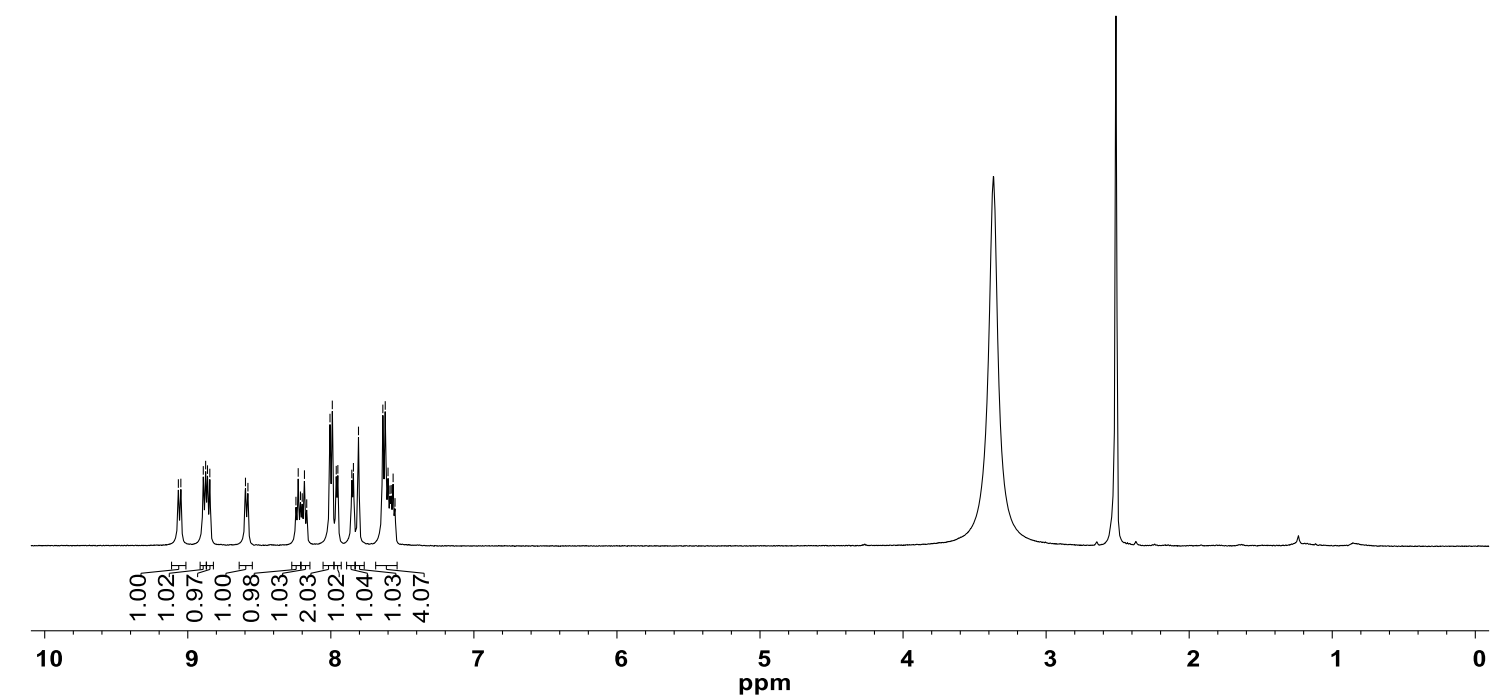

Figure S2. ${ }^{1} \mathrm{H}$ NMR spectrum of $\mathrm{H}_{2} \mathrm{DBB}-\mathrm{Ru}$ in DMSO- $d 6$. 


\section{S2.2 Synthesis and characterization of $\mathrm{Hf}_{12}-\mathrm{Ru}, \mathrm{Hf}_{12}-\mathrm{Ru}-\mathrm{ABA}$, and $\mathrm{Hf}_{12}-\mathrm{Ru}-\mathrm{F} / \mathrm{R}$}

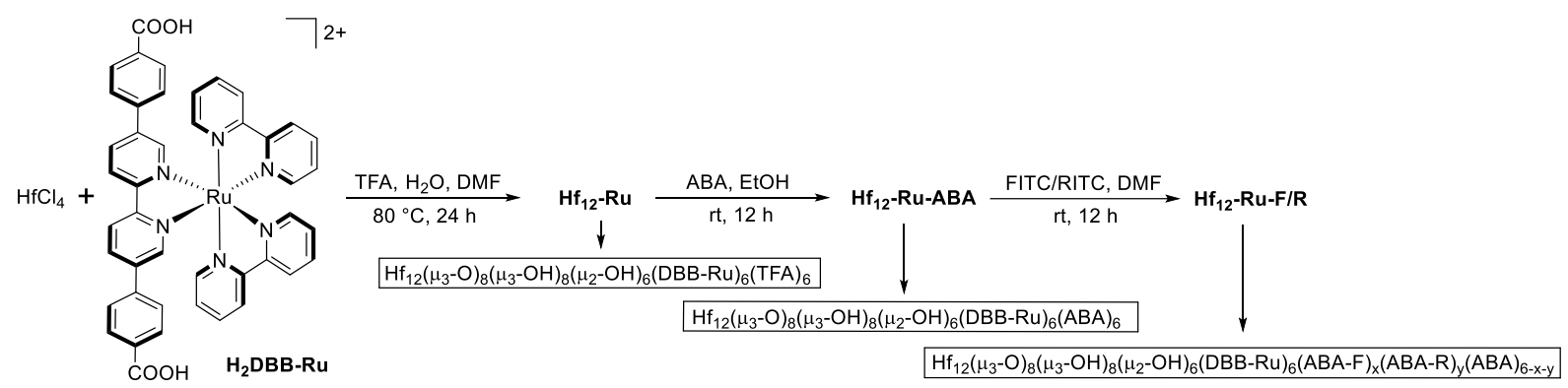

Figure S3. Synthesis route of $\mathrm{Hf}_{12}-\mathrm{Ru}, \mathrm{Hf}_{12}-\mathrm{Ru}-\mathrm{ABA}$, and $\mathrm{Hf}_{12}-\mathrm{Ru}-\mathrm{F} / \mathrm{R}$.

Synthesis of $\mathbf{H f} \mathbf{f}_{\mathbf{1 2}}-\mathbf{R u}$. To a $4 \mathrm{~mL}$ glass vial was added $0.5 \mathrm{~mL}$ of $\mathrm{HfCl}_{4}$ solution $[2.0 \mathrm{mg} / \mathrm{mL}$ in $\mathrm{N}, \mathrm{N}$-dimethylformamide (DMF)], $0.5 \mathrm{~mL}$ of $\mathrm{H}_{2} \mathrm{DBB}-\mathrm{Ru}$ solution (4.0 $\mathrm{mg} / \mathrm{mL}$ in DMF), 2 $\mu \mathrm{L}$ of trifluoroacetic acid (TFA), and $5 \mu \mathrm{L}$ of water. The reaction mixture was kept in an $80{ }^{\circ} \mathrm{C}$ oven for 24 hours. The orange precipitate was collected by centrifugation and washed with DMF and ethanol. The yield was $45 \%$ based on Hf as determined by ICP-MS.
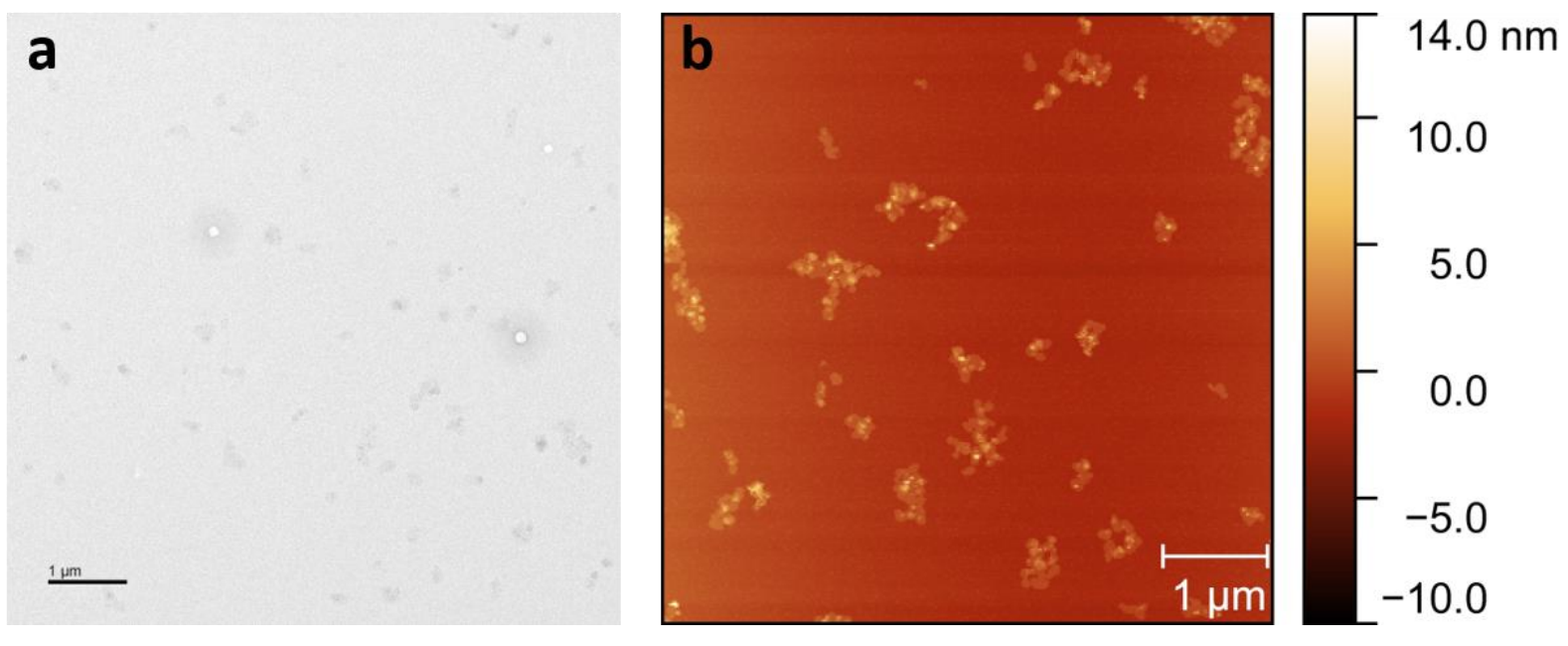

Figure S4. Large-area TEM image (a) and AFM topography (b) of Hf $12-\mathrm{Ru}$.

Digestion of Hf $\mathbf{H}_{12}$-Ru. $1.0 \mathrm{mg} \mathrm{Hf} \mathrm{H}_{12}$-Ru was dried under vacuum. The resulting solid was then digested in a solution of $500 \mu \mathrm{L}$ DMSO- $d_{6}$ and $50 \mu \mathrm{L} \mathrm{D}_{3} \mathrm{PO}_{4}$ and sonicated for $10 \mathrm{~min}$. The mixture was then added $50 \mu \mathrm{L} \mathrm{D}_{2} \mathrm{O}$ and analyzed by ${ }^{1} \mathrm{H}$ NMR. The digested $\mathrm{Hf}_{12}-\mathrm{Ru}$ showed all signals corresponding to $\mathrm{H}_{2} \mathrm{DBB}-\mathrm{Ru}$ without any other aromatic signals. 


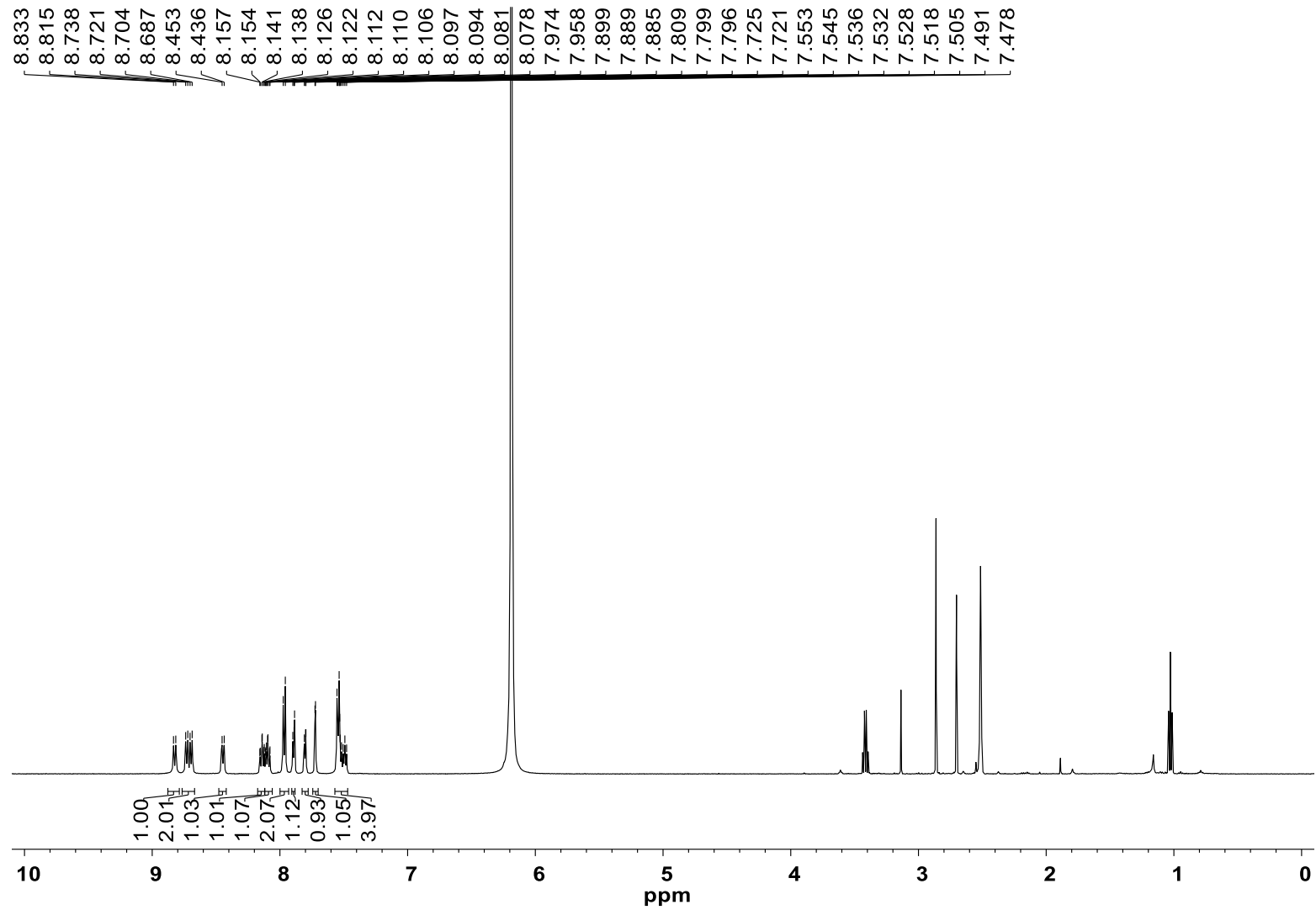

Figure S5. ${ }^{1} \mathrm{H}$ NMR spectrum of digested $\mathrm{Hf}_{12}-\mathrm{Ru}$ in DMSO- $d 6$.

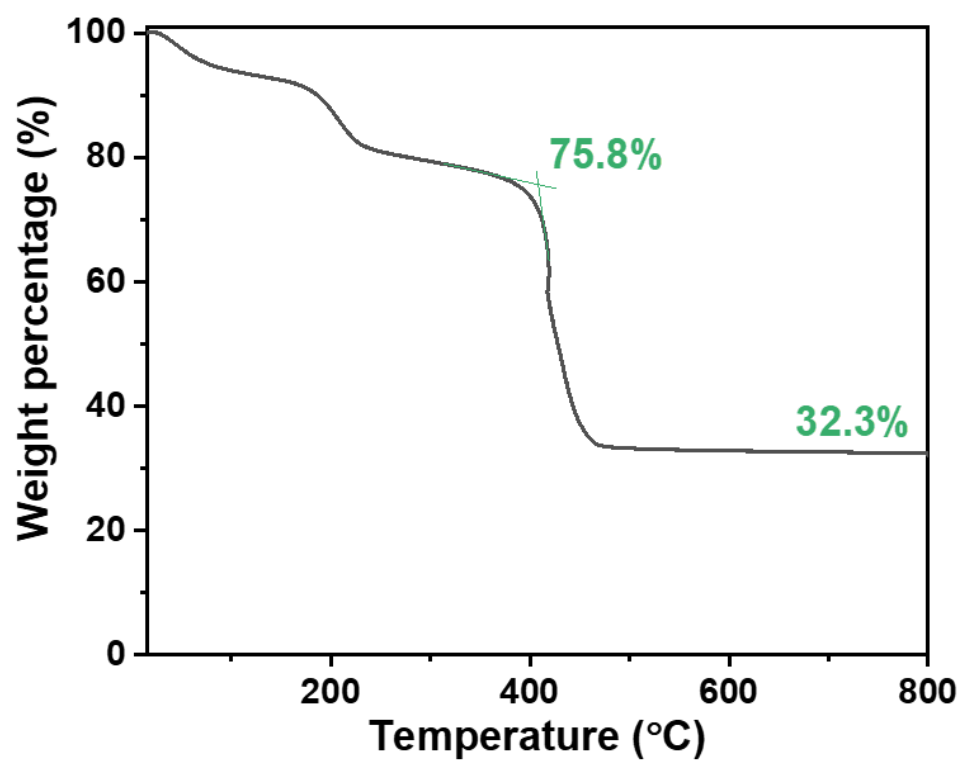

Figure S6. TGA of freshly prepared $\mathrm{Hf}_{12}-\mathrm{Ru}$. The first weight loss in the $25-400{ }^{\circ} \mathrm{C}$ temperature range corresponds to removal of adsorbed solvents in the pores. The second weight loss $(57.4 \%)$ in the $400-800{ }^{\circ} \mathrm{C}$ temperature range corresponds to decomposition of $\mathrm{Hf}_{12}\left(\mu_{3}-\mathrm{O}\right)_{8}\left(\mu_{3}-\mathrm{OH}\right)_{8}\left(\mu_{2}-\mathrm{OH}\right)_{6}(\mathrm{DBB}-\mathrm{Ru})_{6}(\mathrm{TFA})_{6}$ to $\left(12 \mathrm{HfO}_{2}+6 \mathrm{RuO}_{2}\right)$, which has an expected weight loss of $58.6 \%$. 
Synthesis of Hf $\mathbf{H}_{12}-\mathbf{R u}-\mathbf{A B A}$. To a $4 \mathrm{~mL}$ glass vial was added $1 \mathrm{~mL}$ of $\mathrm{Hf}_{12}-\mathrm{Ru}$ suspension (2 $\mathrm{mM}$ based on $\mathrm{Hf}$ in $\mathrm{EtOH}$ ) and $0.5 \mathrm{mg}$ of 4 -aminobenzoic acid (ABA). The reaction mixture was stirred overnight at room temperature. The orange precipitate was collected by centrifugation and washed with ethanol twice. The yield was $89 \%$ based on Hf as determined by ICP-MS.

Analysis of digested Hf $\mathbf{H}_{12}-\mathbf{R u}-\mathbf{A B A}$ by ${ }^{1} \mathbf{H}$ NMR. To determine the ratio of the ABA ligands and DBB-Ru ligands in $\mathrm{Hf}_{12}-\mathrm{Ru}-\mathrm{ABA}, 2.0 \mathrm{mg}$ of $\mathrm{Hf}_{12}-\mathrm{Ru}-\mathrm{ABA}$ was dried under vacuum and then digested in a solution of $500 \mu \mathrm{L}$ DMSO- $d_{6}$ and $50 \mu \mathrm{L} \mathrm{D}_{3} \mathrm{PO}_{4}$. The mixture was then sonicated for $10 \mathrm{~min}$, to which $50 \mu \mathrm{L} \mathrm{D}_{2} \mathrm{O}$ was added, and analyzed by ${ }^{1} \mathrm{H} \mathrm{NMR}$. The ratio of ABA ligand and DBB-Ru ligand was approximately 1:1 as determined by comparing the peaks corresponding to each ligand in ${ }^{1} \mathrm{H}$ NMR, which is consistent with the formulation of $\mathrm{Hf}_{12}\left(\mu_{3}-\mathrm{O}\right)_{8}\left(\mu_{3}-\mathrm{OH}\right)_{8}\left(\mu_{2}-\mathrm{OH}\right)_{6}(\mathrm{DBB}-\mathrm{Ru})_{6}(\mathrm{ABA})_{6}$ and indicates complete carboxylate exchange between ABA and trifluoroacetate.

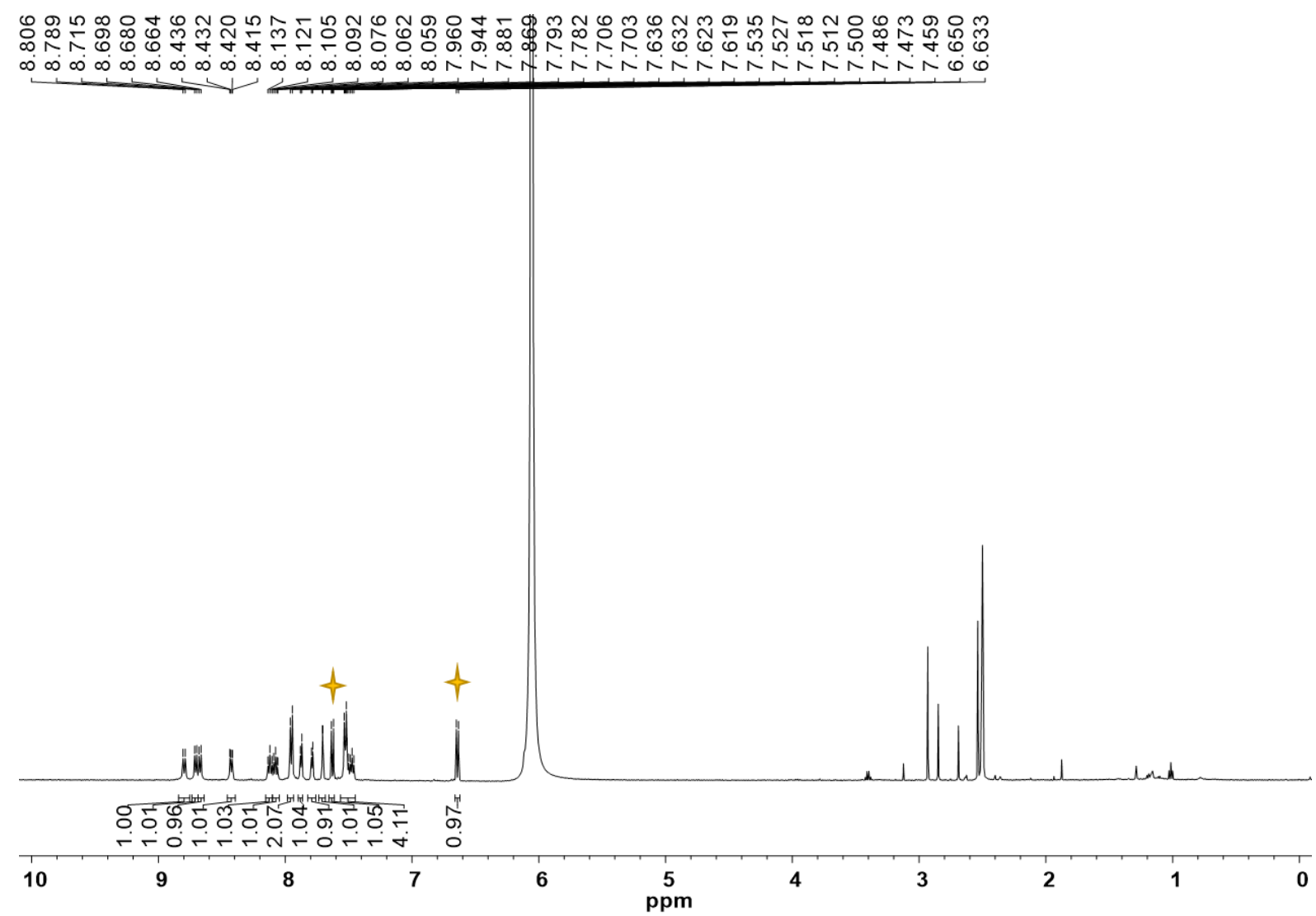

Figure S7. NMR spectrum of digested $\mathrm{Hf}_{12}-\mathrm{Ru}-\mathrm{ABA}$. Peaks labeled with yellow stars correspond to $\mathrm{ABA}$. 
Synthesis of $\mathbf{H f}_{12}-\mathbf{R u}-\mathbf{F} / \mathbf{R}$. To a $4 \mathrm{~mL}$ glass vial was added $1 \mathrm{~mL}$ of $\mathrm{Hf}_{12}-\mathrm{Ru}-\mathrm{ABA}$ suspension (2.0 mM based on $\mathrm{Hf}$ and $1.0 \mathrm{mM}$ based on $\mathrm{Ru}$ in DMF), 500 or $20 \mu \mathrm{M}$ fluorescein isothiocyanate (FITC), and 500 or $200 \mu \mathrm{M}$ Rhodamine-B isothiocyanate (RITC). The reaction mixture was stirred at room temperature overnight. The orange precipitate was collected by centrifugation and washed with DMF and ethanol.

UV-Vis determination. When the feed concentrations of FITC and RITC were $500 \mu \mathrm{M}$ and $500 \mu \mathrm{M}$, the FITC and RITC loadings were $\sim 31.5 \%$ and $\sim 10.1 \%$, based on the absorbance ratio between FITC and RITC to DBB-Ru as determined by UV-Vis spectroscopy (Figures 2a and S11-14), respectively. When the concentration of DBB-Ru in $\mathrm{Hf}_{12}-\mathrm{Ru}-\mathrm{F} / \mathrm{R}$ was $10.0 \mu \mathrm{M}$ as determined by ICP-MS, the readout of its UV-Vis absorbance at $489 \mathrm{~nm}$ and $565 \mathrm{~nm}$ were 0.181 and 0.063 , respectively.

FITC: $(0.181-0.00659 * 10) / 0.03652=3.15 \mu \mathrm{M}, 3.15 / 10.0=31.5 \%$

RITC: $(0.063-0.00135 * 10) / 0.04923=1.01 \mu \mathrm{M}, 1.01 / 10.0=10.1 \%$

Luminescence determination. When the feed concentrations of FITC and RITC were 20 $\mu \mathrm{M}$ and $200 \mu \mathrm{M}$, the FITC and RITC loadings were $\sim 1.1 \%$ and $\sim 5.6 \%$, based on the ratio between FITC and RITC to DBB-Ru as determined by luminescence intensity (Figures 2b and S15-17), respectively. When the concentration of DBB-Ru in $\mathrm{Hf}_{12}-\mathrm{Ru}-\mathrm{F} / \mathrm{R}$ was $10.0 \mu \mathrm{M}$ as determined by ICP-MS, the readouts of fluorescence signals at $514 \mathrm{~nm}$ and $576 \mathrm{~nm}$ were 19.37 and 20.46, respectively.

FITC: $19.37 / 175.9=0.11 \mu \mathrm{M}, 0.11 / 10.0=1.1 \%$

RITC: $20.46 / 36.5=0.56 \mu \mathrm{M}, 0.56 / 10.0=5.6 \%$

HRMS analysis of digested $\mathrm{Hf}_{12}-\mathrm{Ru}-\mathrm{F} / \mathrm{R}$. To demonstrate covalent modification of FITC and RITC through thiourea linkage in $\mathrm{Hf}_{12}-\mathrm{Ru}-\mathrm{F} / \mathrm{R}, 0.1 \mathrm{mg}$ of $\mathrm{Hf}_{12}-\mathrm{Ru}-\mathrm{F} / \mathrm{R}$ (FITC: $31.5 \%$, RITC: $10.1 \%$ ) was dried under vacuum and then digested in a solution of $500 \mu \mathrm{L}$ DMSO and $50 \mu \mathrm{L} \mathrm{D} \mathrm{PO}_{4}$. The mixture was then sonicated for 10 min and analyzed by HRMS (Figure $2 \mathrm{~g})$. 

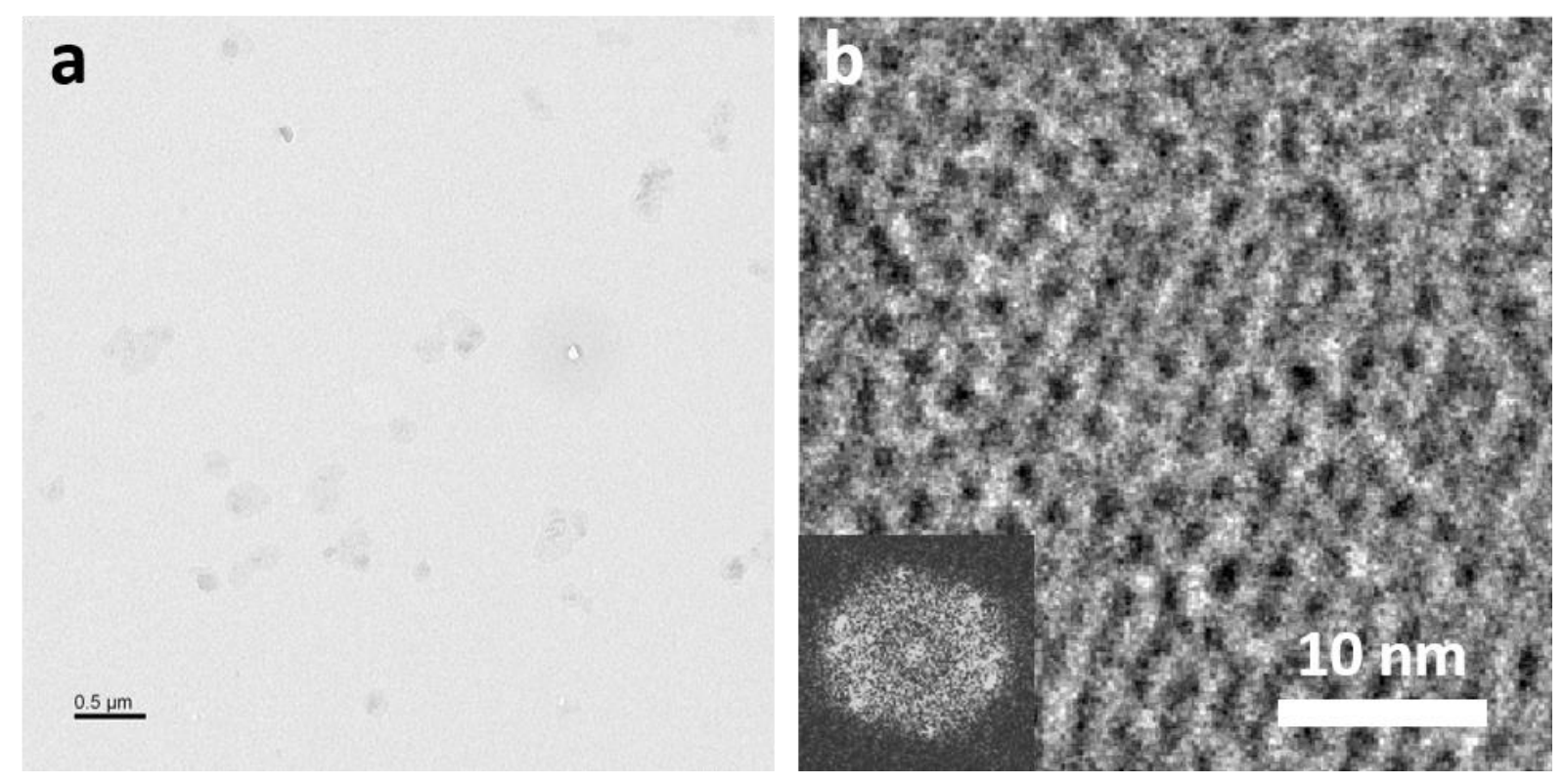

Figure S8. Large-area TEM image (a) and HRTEM (b) of $\mathrm{Hf}_{12}-\mathrm{Ru}-\mathrm{F} / \mathrm{R}$.

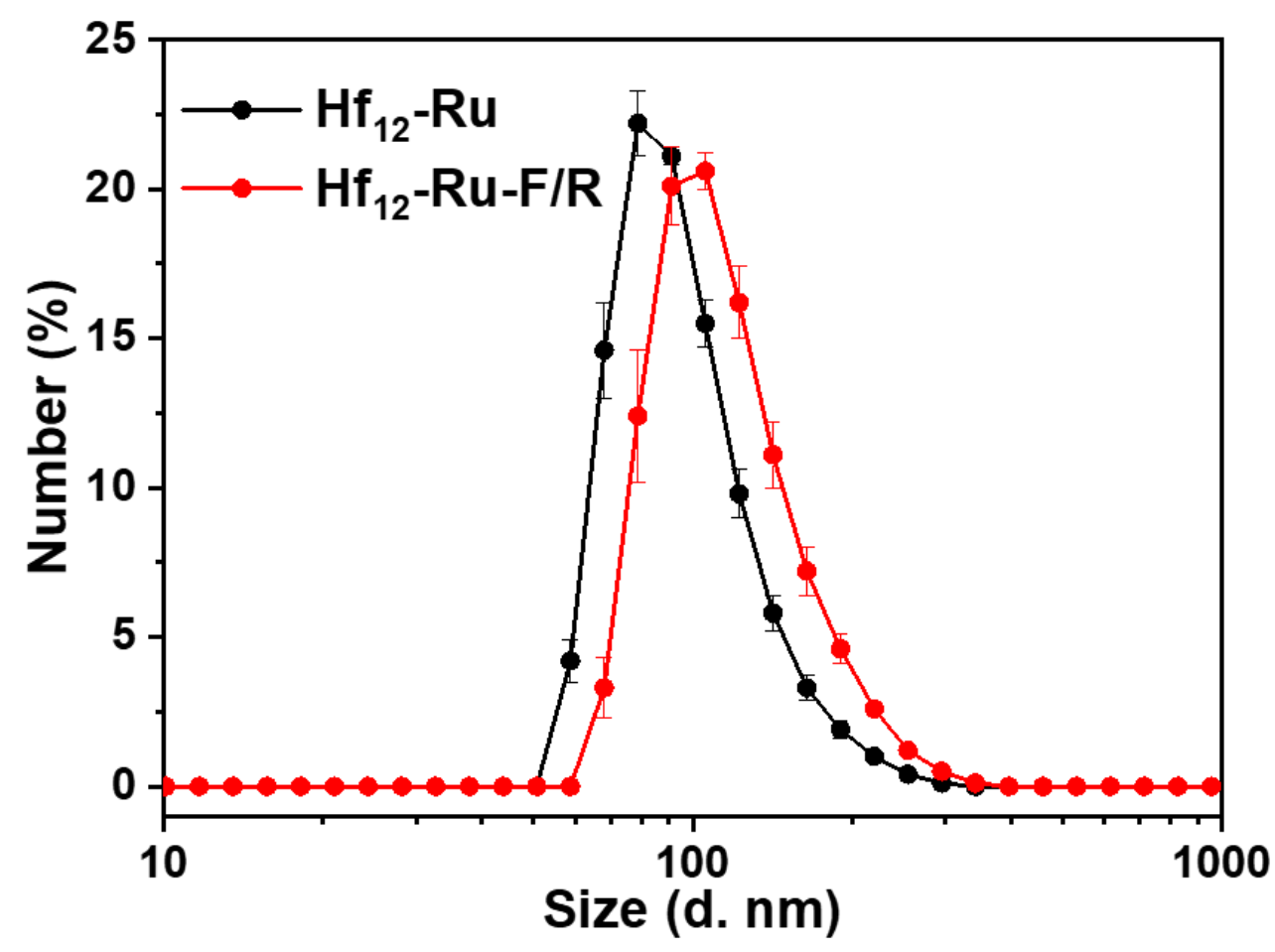

Figure S9. Number-averaged diameters of $\mathrm{Hf}_{12}-\mathrm{Ru}(98.5 \pm 2.2 \mathrm{~nm})$ and $\mathrm{Hf}_{12}-\mathrm{Ru}-\mathrm{F} / \mathrm{R}(119.1 \pm$ $2.3 \mathrm{~nm}$ ) in $\mathrm{EtOH}$. 


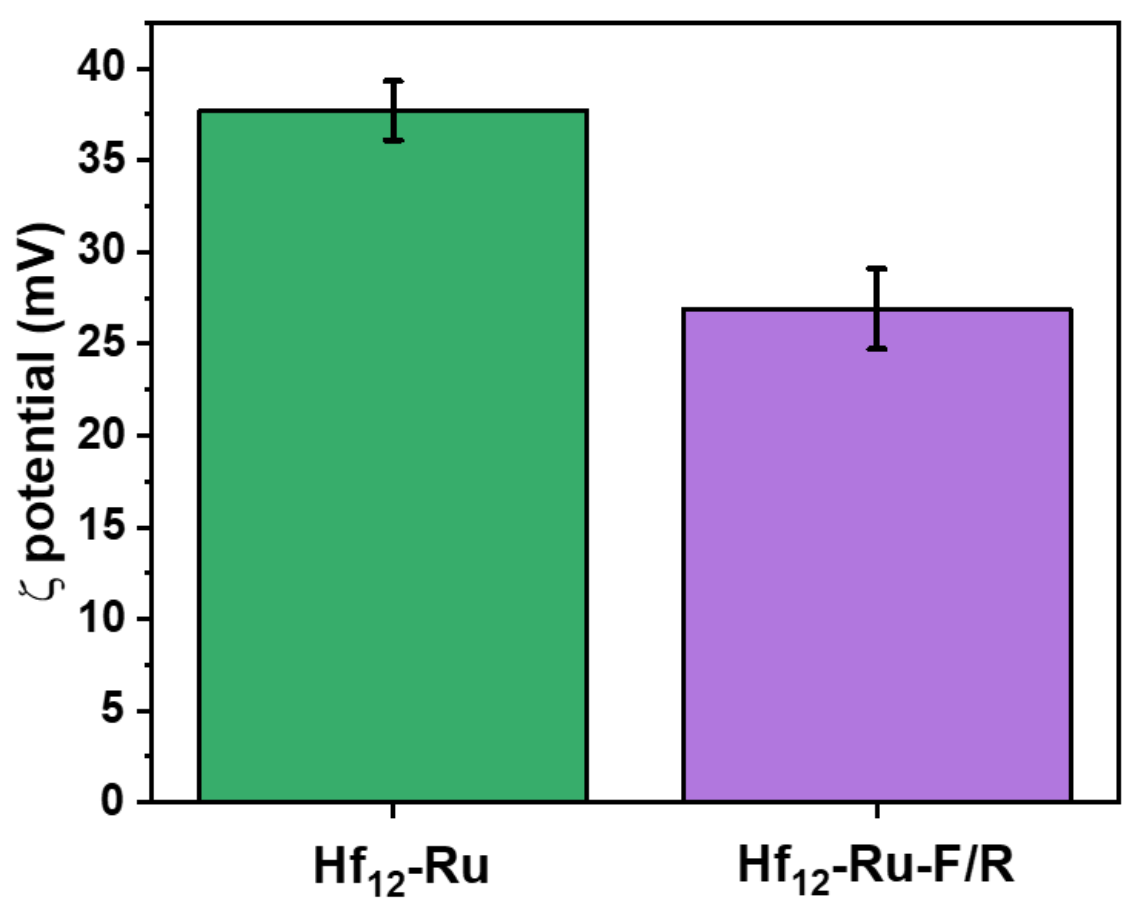

Figure S10. $\zeta$ potential of $\mathrm{Hf}_{12}-\mathrm{Ru}(37.7 \pm 1.6 \mathrm{mV})$ and $\mathrm{Hf}_{12}-\mathrm{Ru}-\mathrm{F} / \mathrm{R}(26.9 \pm 2.2 \mathrm{mV})$ in water. 


\section{S3. Luminescence Analysis}

\section{S3.1 UV-Vis analysis}
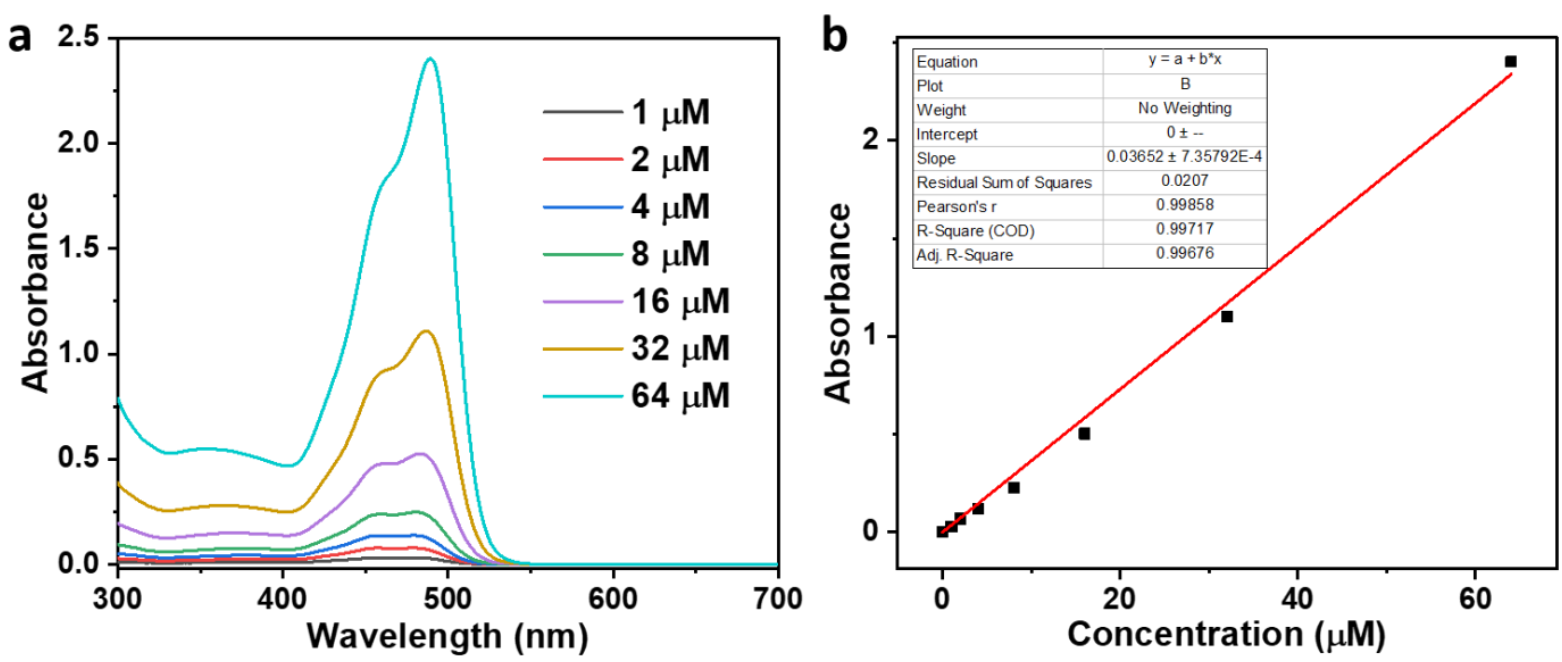

Figure S11. UV-Vis spectra of FITC in water (a) and its linear fit between the absorbance at $489 \mathrm{~nm}$ and the concentration (b).
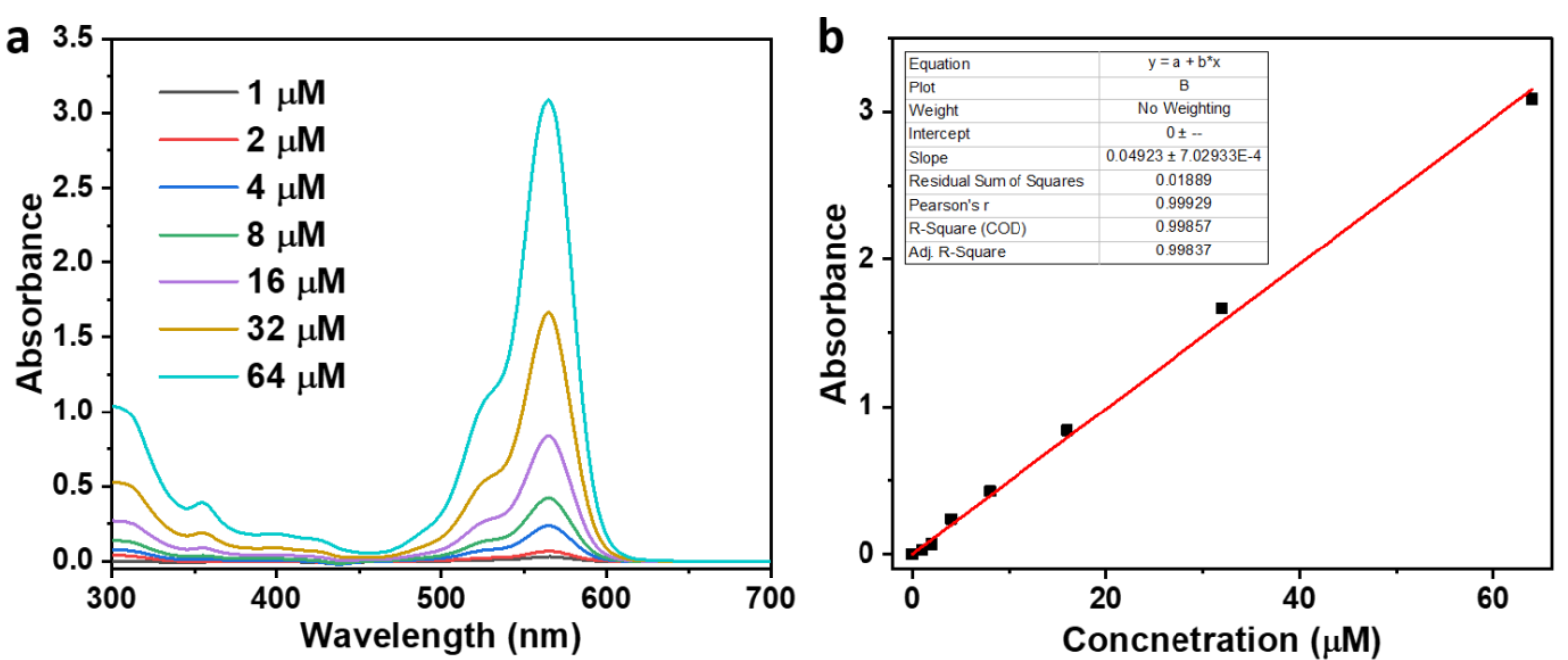

Figure S12. UV-Vis spectra of RITC in water (a) and its linear fit between the absorbance at $565 \mathrm{~nm}$ and the concentration (b). 

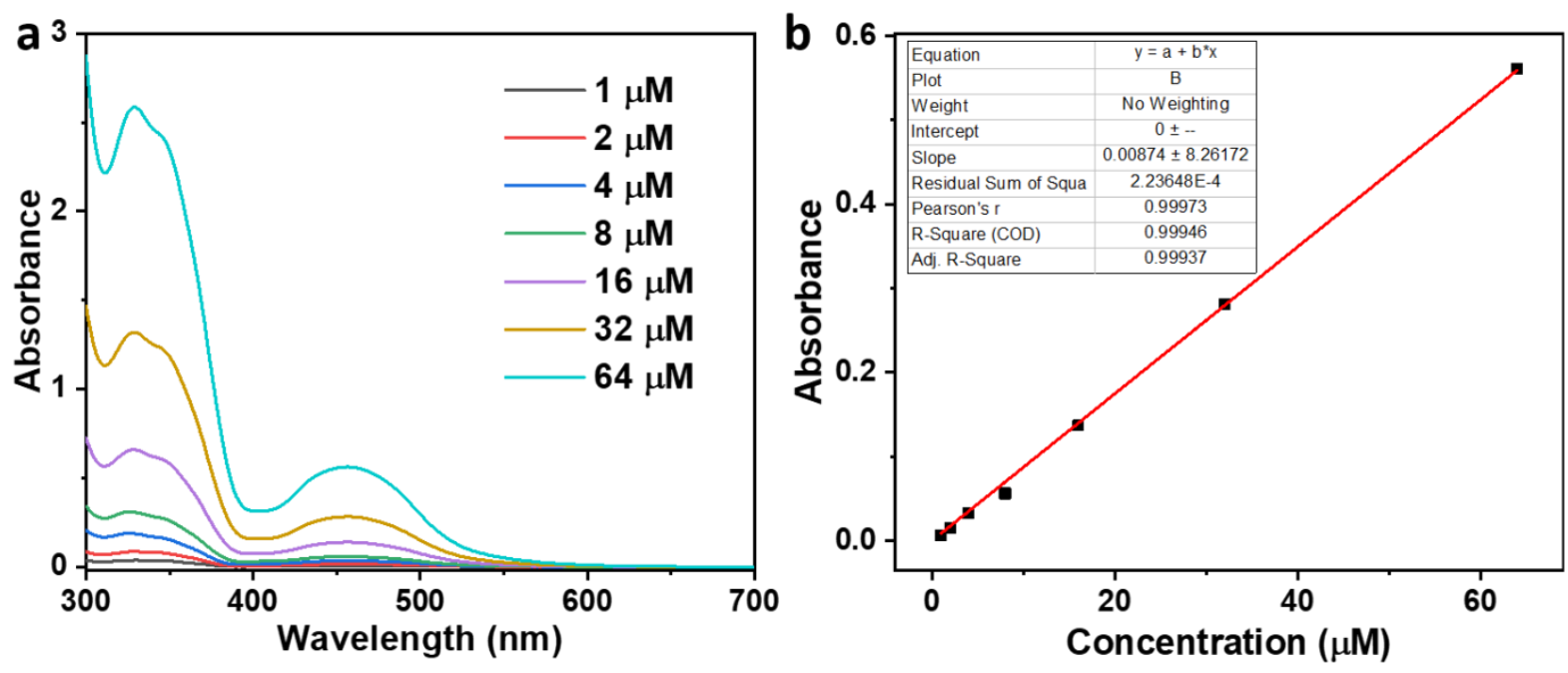

Figure S13. UV-Vis spectra of $\mathrm{H}_{2} \mathrm{DBB}-\mathrm{Ru}$ in water (a) and its linear fit between the absorbance at $465 \mathrm{~nm}$ and the concentration (b).
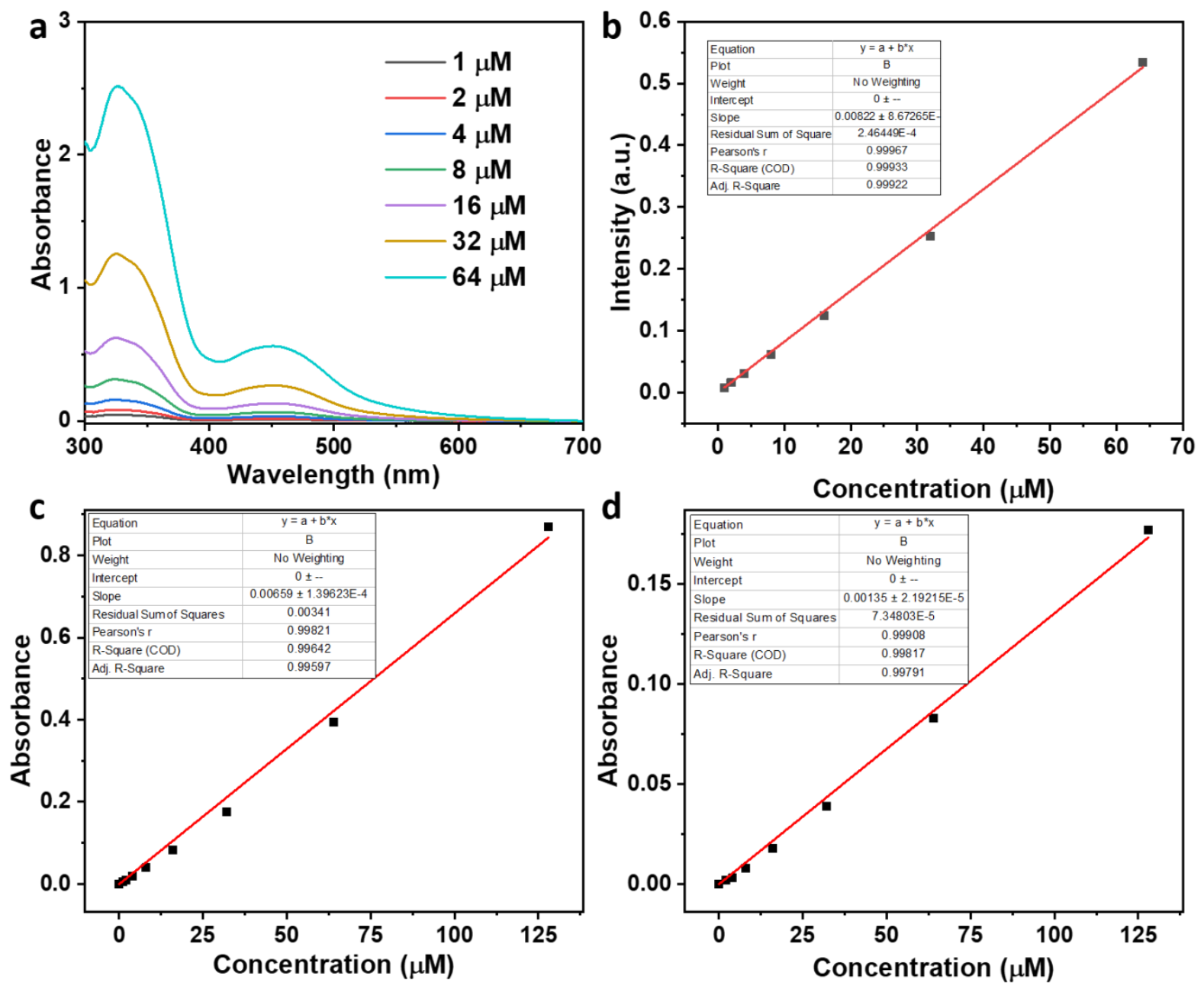

Figure S14. UV-Vis spectra of $\mathrm{Hf}_{12}-\mathrm{Ru}$ in water (a) and its linear fits between the absorbance at $465 \mathrm{~nm}(\mathrm{~b}), 489 \mathrm{~nm}(\mathrm{c})$, or $565 \mathrm{~nm}(\mathrm{~d})$ and the concentration. 


\section{S3.2 Emission spectra}
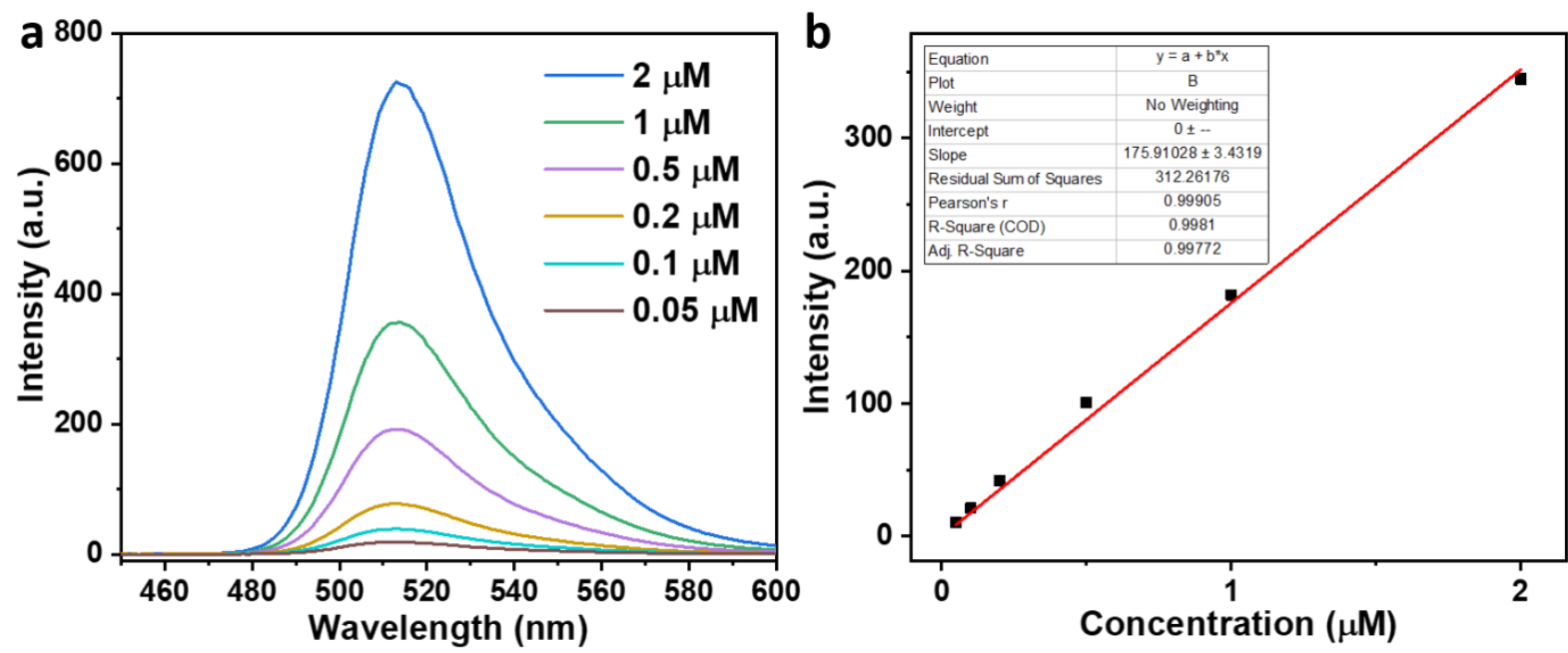

Figure S15. Emission spectra of FITC in water (a) and its linear fit between the emission intensity at $514 \mathrm{~nm}$ and the concentration (b).
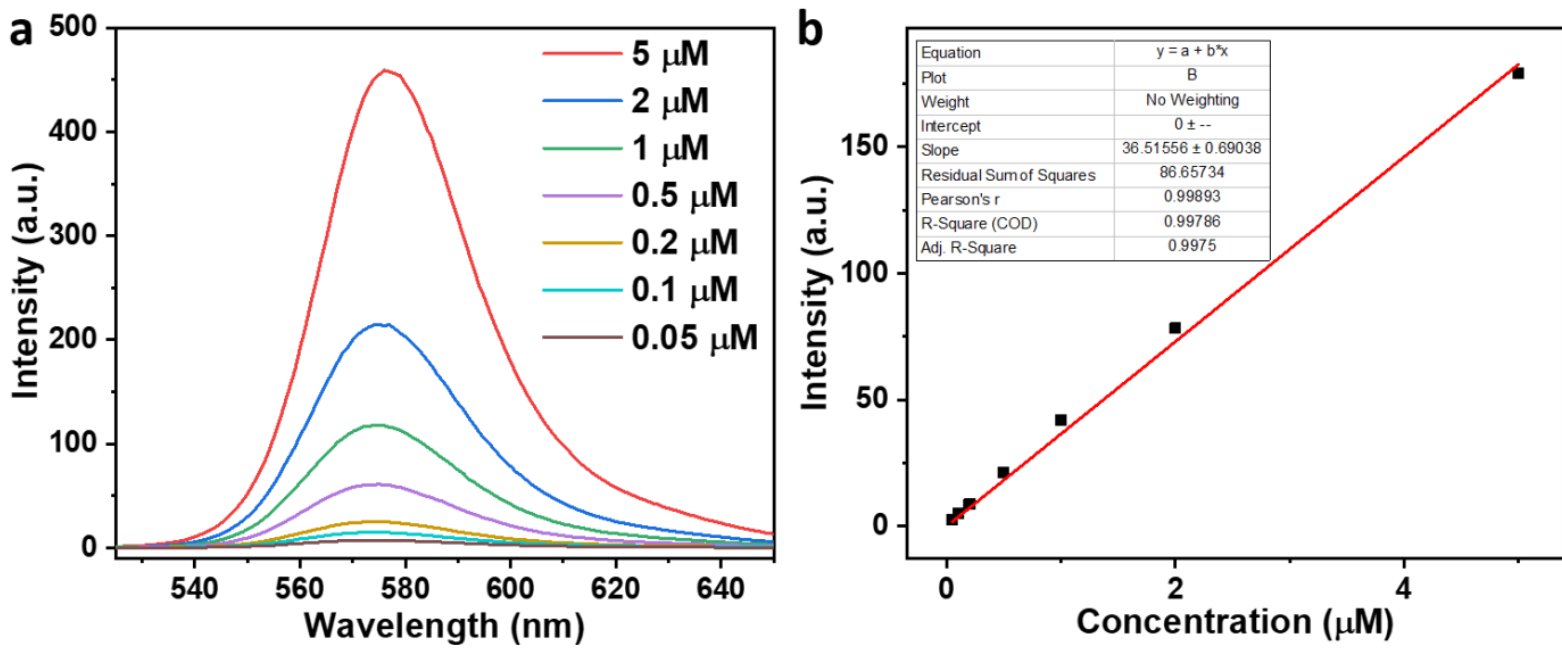

Figure S16. Emission spectra of RITC in water (a) and its linear fit between the emission intensity at $576 \mathrm{~nm}$ and the concentration (b). 

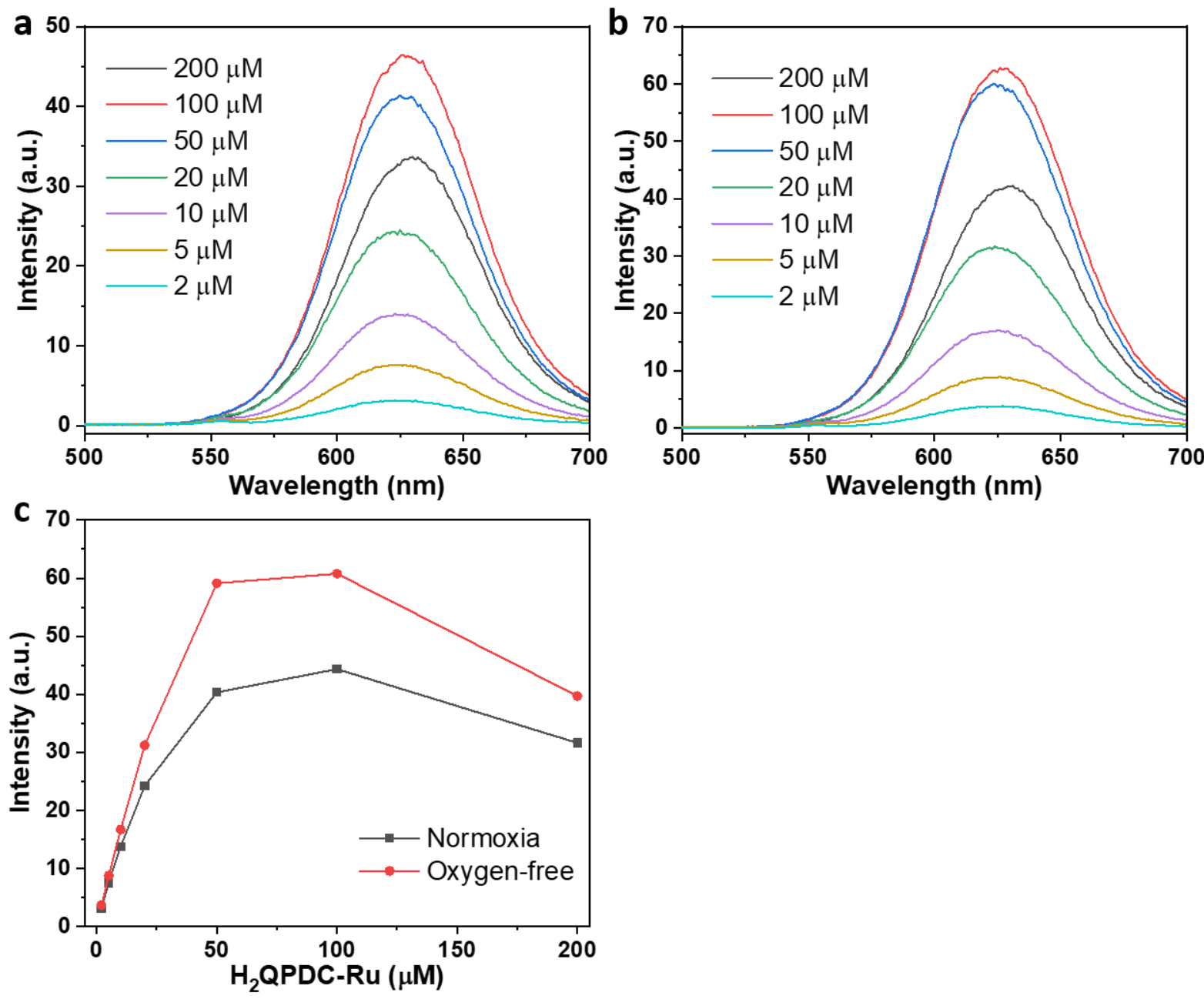

Figure S17. Emission spectra of $\mathrm{H}_{2} \mathrm{DBB}-\mathrm{Ru}$ in water at normoxia (a) or oxygen-free (b) conditions and plots of their emission intensities at $628 \mathrm{~nm}$ at different concentrations (c).

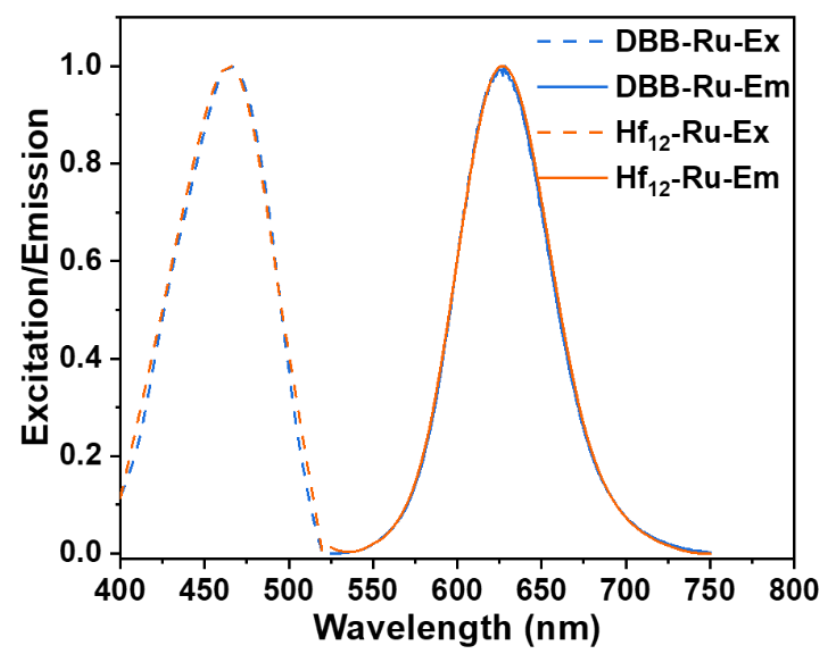

Figure S18. Normalized excitation and emission spectra of $\mathrm{Hf}_{12}-\mathrm{Ru}$ in comparison to those of $\mathrm{H}_{2} \mathrm{DBB}-\mathrm{Ru}$ in water. 


\section{S3.3 Fitting equations}

Fitting equation for pH as measured by FITC. HA and A were used herein to refer to mono- and di-anionic forms of FITC, respectively. ${ }^{2}$ The concentration of each species is:

$$
\begin{aligned}
& {[H A]=c_{\mathrm{F}} \frac{\left[H^{+}\right]}{\left[H^{+}\right]+K}} \\
& {\left[A^{-}\right]=c_{\mathrm{F}} \frac{K}{\left[H^{+}\right]+K}}
\end{aligned}
$$

Where $c_{\mathrm{F}}$ is the total concentration of FITC, and $\mathrm{K}$ is the dissociation constant of the aforementioned step.

The luminescence intensity $\left(I_{\mathrm{f}}\right)$ is linearly correlated to FITC species concentrations:

$$
I_{f}=I_{0} \phi_{f} \varepsilon l c=k c
$$

where $I_{0}, \phi_{\mathrm{f}}, \varepsilon, l$, and $c$ are incident light intensity, quantum yield, extinction coefficient, path length, and the FITC species concentrations, respectively.

The luminescence intensity of FITC is:

$$
I_{\mathrm{F}}=k_{1}[H A]+k_{2}\left[A^{-}\right]=k_{1} c_{\mathrm{F}} \frac{\left[H^{+}\right]}{\left[H^{+}\right]+K}+k_{2} c_{\mathrm{F}} \frac{K}{\left[H^{+}\right]+K}=c_{\mathrm{F}} \frac{k_{1}\left[H^{+}\right]+k_{2} K}{\left[H^{+}\right]+K}
$$

Therefore, the luminescence intensity of FITC against proton activity fits a rational function in a form of:

$$
\begin{aligned}
I_{\mathrm{F}} & =\frac{\mathrm{A}_{1}\left[H^{+}\right]+\mathrm{B}_{1}}{\left[H^{+}\right]+\mathrm{C}_{1}}(E \mathrm{q} . \mathrm{S} 1) \\
& =\frac{\mathrm{A}_{1} e^{-2.303 p H}+\mathrm{B}_{1}}{e^{-2.303 p H}+\mathrm{C}_{1}}(\text { Eq.S } 2)
\end{aligned}
$$

where

$$
\begin{gathered}
\mathrm{A}_{1}=c_{\mathrm{F}} k_{1} \\
\mathrm{~B}_{1}=c_{\mathrm{F}} k_{2} K \\
\mathrm{C}_{1}=K
\end{gathered}
$$


Based on this hypothesis, we fitted the FITC luminescence intensity with different $\mathrm{pH}$ values, which gave the following results:

(1) For $0.11 \mu \mathrm{M}$ free FITC solution measured by fluorimeter:

$$
\begin{aligned}
I_{\mathrm{F}} & =\frac{1.00\left[\mathrm{H}^{+}\right]+3.91 \times 10^{-6}}{\left[\mathrm{H}^{+}\right]+2.88 \times 10^{-7}}(\text { Figure S20b }) \\
& =\frac{1.00 e^{-2.303 p H}+3.91 \times 10^{-6}}{e^{-2.303 p H}+2.88 \times 10^{-7}}(\text { Figure S22a })
\end{aligned}
$$

(2) For $0.11 \mu \mathrm{M}$ FITC on $\mathrm{Hf}_{12}-\mathrm{Ru}-\mathrm{F} / \mathrm{R}$ suspension measured by fluorimeter:

$$
\begin{aligned}
I_{\mathrm{F}} & =\frac{0.88\left[\mathrm{H}^{+}\right]+3.70 \times 10^{-6}}{\left[\mathrm{H}^{+}\right]+3.03 \times 10^{-7}}(\text { Figure S23b }) \\
& =\frac{0.88 e^{-2.303 p H}+3.70 \times 10^{-6}}{e^{-2.303 p H}+3.03 \times 10^{-7}}(\text { Figure } 2 \mathrm{a})
\end{aligned}
$$

The luminescence intensity of RITC $\left(I_{\mathrm{R}}\right)$ is linearly correlated to RITC concentrations:

$$
I_{\mathrm{R}}=k_{3} c_{\mathrm{R}}
$$

Where $c_{\mathrm{R}}$ is the total concentration of RITC

The luminescence intensity ratio between FITC and RITC is:

$$
r_{\mathrm{F} / \mathrm{R}}=\frac{I_{\mathrm{F}}}{I_{\mathrm{R}}}=\frac{c_{\mathrm{F}}}{k_{3} c_{\mathrm{R}}} \frac{k_{1}\left[H^{+}\right]+k_{2} K}{\left[H^{+}\right]+K}
$$

Therefore, the luminescence intensity ratio between FITC and RITC against proton activity fits a rational function of the form:

$$
\begin{aligned}
r & =\frac{\mathrm{A}_{2}\left[H^{+}\right]+\mathrm{B}_{2}}{\left[H^{+}\right]+\mathrm{C}_{2}}(\text { Eq. S3) } \\
& =\frac{\mathrm{A}_{2} e^{-2.303 p H}+\mathrm{B}_{2}}{e^{-2.303 p H}+\mathrm{C}_{2}} \text { (Eq. S4) }
\end{aligned}
$$

where

$$
\begin{gathered}
\mathrm{A}_{2}=\frac{c_{\mathrm{F}} k_{1}}{k_{3} c_{\mathrm{R}}} \\
\mathrm{B}_{2}=\frac{c_{\mathrm{F}} k_{2} K}{k_{3} c_{\mathrm{R}}} \\
\mathrm{C}_{2}=K
\end{gathered}
$$


Based on this hypothesis, we fitted the luminescence intensity ratio between FITC and RITC at different $\mathrm{pH}$ values, which gave the following results:

(3) For $0.11 \mu \mathrm{M}$ FITC and $0.56 \mu \mathrm{M}$ RITC in $\mathrm{Hf}_{12}-\mathrm{Ru}-\mathrm{F} / \mathrm{R}$ suspension measured by Xenogen IVIS 200 imaging:

$$
\begin{aligned}
r_{\mathrm{F} / \mathrm{R}} & =\frac{0.119\left[\mathrm{H}^{+}\right]+3.91 \times 10^{-7}}{\left[H^{+}\right]+3.28 \times 10^{-7}}(\text { Figure S27a }) \\
& =\frac{0.119 e^{-2.303 p H}+3.91 \times 10^{-7}}{e^{-2.303 p H}+3.28 \times 10^{-7}}(\text { Figure } 2 \mathrm{e})
\end{aligned}
$$

Fitting equation for $\mathrm{O}_{2}$ as measured by DBB-Ru. The luminescence quenching of DBB-Ru (in both $\mathrm{H}_{2} \mathrm{DBB}-\mathrm{Ru}$ and $\mathrm{Hf}_{12}-\mathrm{Ru}-\mathrm{F} / \mathrm{R}$ ) was fitted to the Stern-Völmer equation:

$$
\frac{I_{0}}{I_{\mathrm{Ru}}}=1+K_{\mathrm{SV}} P_{\mathrm{O}_{2}} \text { (Eq. S5) }
$$

where $I_{0}, I_{\mathrm{Ru}}, P_{\mathrm{O} 2}$ and $K \mathrm{~Sv}$ are the luminescence intensity of DBB-Ru in the absence of $\mathrm{O}_{2}$, the luminescence intensity of $\mathrm{DBB}-\mathrm{Ru}$ in the presence of $\mathrm{O}_{2}$, the $\mathrm{O}_{2}$ pressure, and the Stern-Völmer constant, respectively.

Therefore, the luminescence intensity of $\mathrm{DBB}-\mathrm{Ru}$ against $\mathrm{O}_{2}$ pressure fits a rational function in a form of:

$$
I_{\mathrm{Ru}}=\frac{I_{0}}{1+K_{\mathrm{SV}} P_{\mathrm{O}_{2}}}=\frac{\mathrm{A}_{3}}{1+\mathrm{B}_{3} P_{\mathrm{O}_{2}}}(\text { Eq. S6) }
$$

where

$$
\begin{gathered}
\mathrm{A}_{3}=I_{0} \\
\mathrm{~B}_{3}=K_{\mathrm{SV}}
\end{gathered}
$$

Based on this hypothesis, we fitted the DBB-Ru luminescence intensity ratio under different $\mathrm{O}_{2}$ pressures, which gave the following results:

(4) For $10.0 \mu \mathrm{M}$ free $\mathrm{H}_{2} \mathrm{DBB}-\mathrm{Ru}$ solution measured by fluorimeter:

$$
\begin{aligned}
& \frac{I_{0}}{I_{\mathrm{Ru}}}=1+0.00285 P_{\mathrm{O}_{2}}(\text { Figure S21b) } \\
& I_{\mathrm{Ru}}=\frac{17.760}{1+0.00285 P_{\mathrm{O}_{2}}}(\text { Figure S22b })
\end{aligned}
$$


(5) For $10.0 \mu \mathrm{M} \mathrm{Hf}{ }_{12}-\mathrm{Ru}-\mathrm{F} / \mathrm{R}$ suspension measured by fluorimeter:

$$
\begin{aligned}
& \frac{I_{0}}{I_{\mathrm{Ru}}}=1+0.00285 P_{\mathrm{O}_{2}}(\text { Figure S24b) } \\
& I_{\mathrm{Ru}}=\frac{16.767}{1+0.00253 P_{\mathrm{O}_{2}}}(\text { Figure } 2 \mathrm{~d})
\end{aligned}
$$

The luminescence intensity ratio between $\mathrm{DBB}-\mathrm{Ru}$ and $\mathrm{RITC}$ in $\mathrm{Hf}_{12}-\mathrm{Ru}-\mathrm{F} / \mathrm{R}$ was also fitted to the Stern-Völmer equation:

$$
\frac{\left(r_{R u / R}\right)_{0}}{r_{R u / R}}=1+K_{\mathrm{SV}} P_{\mathrm{O}_{2}} \text { (Eq. S7) }
$$

where $\left(r_{R u / R}\right)_{0}$ and $r_{R u / R}$ are the luminescence intensity ratios between DBB-Ru and RITC in the absence and presence of $\mathrm{O}_{2}$, respectively.

Therefore, the luminescence intensity ratio between DBB-Ru and RITC against $\mathrm{O}_{2}$ pressure fits a rational function of the form:

$$
\begin{gathered}
r_{\mathrm{Ru} / \mathrm{R}}=\frac{I_{\mathrm{Ru}}}{I_{\mathrm{R}}}=\frac{I_{0}}{k_{3} c_{\mathrm{R}}\left(1+K_{\mathrm{SV}} P_{\mathrm{O}_{2}}\right)}=\frac{\mathrm{A}_{4}}{1+\mathrm{B}_{4} P_{\mathrm{O}_{2}}} \text { (Eq. S8) } \\
\mathrm{A}_{4}=\frac{I_{0}}{k_{3} c_{\mathrm{R}}} \\
\mathrm{B}_{4}=K_{\mathrm{SV}}
\end{gathered}
$$

Based on this hypothesis, we fitted the luminescence intensity ratio between DBB-Ru and RITC at different $\mathrm{O}_{2}$ partial pressures, which gave the following results:

(6) For $10.0 \mu \mathrm{M}$ DBB-Ru and $0.56 \mu \mathrm{M}$ RITC in $\mathrm{Hf}_{12}-\mathrm{Ru}-\mathrm{F} / \mathrm{R}$ suspension measured by Xenogen IVIS 200 imaging:

$$
\begin{aligned}
\frac{\left(r_{R u / R}\right)_{0}}{r_{R u / R}} & =1+0.00237 P_{\mathrm{O}_{2}}(\text { Figure S27b) } \\
r_{R u / R} & =\frac{1.613}{1+0.00237 P_{\mathrm{O}_{2}}}(\text { Figure } 2 \mathrm{f})
\end{aligned}
$$




\section{S3.4 Standard curves as determined by fluorimetry}

pH adjustment. To a $0.6 \mathrm{mM}$ PBS was added $1 \mathrm{M} \mathrm{NaOH}$ or $\mathrm{HCl}$ to adjust the $\mathrm{pH}$ to 4.0-8.0. The $\mathrm{pH}$ value of these PBS was determined ot be 4.01, 4.45, 4.99, 5.57, 5.94, 6.46, 7.04, 7.49, and 8.00, respectively, by an accumet $\mathrm{AB} 150 \mathrm{pH}$ meter.

$\mathrm{O}_{2}$ pressure adjustment. Into a glove box was blown the mixture of $\mathrm{N}_{2}$ and Air with the Air percentages of $0,20 \%, 40 \%, 60 \%, 80 \%$, and $100 \%$ to afford the $\mathrm{O}_{2}$ pressure of $\sim 0, \sim 32, \sim 64$, $\sim 96, \sim 128$, and $\sim 160 \mathrm{mmHg}$, respectively. The exact $\mathrm{O}_{2}$ pressure at each condition was measured by a commercial oxygen sensor (YSI ProODO 626279).

Luminescence spectra and quantification. The luminescence spectra of DBB-Ru, FITC, and RITC at different $\mathrm{pH}$ and $\mathrm{O}_{2}$ pressure were measured by an RF-5301PC fluorimeter (Shimadzu, Japan) at spectrum mode with excitation wavelength at $430 \mathrm{~nm}, 465 \mathrm{~nm}$, and 535 $\mathrm{nm}$, respectively. The intensity quantification of DBB-Ru, FITC, and RITC at different $\mathrm{pH}$ and $\mathrm{O}_{2}$ pressure was measured at quantitative mode with excitation/emission parameters shown in Figure S19. Each quantitative measurement was repeated three times.

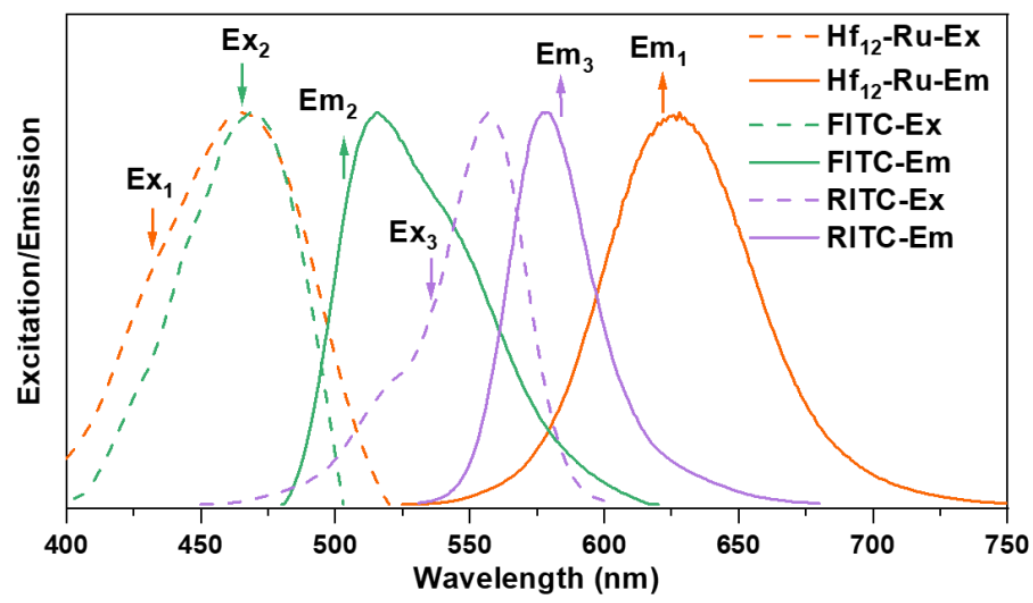

Figure S19. Excitation and emission spectra of $\mathrm{Hf}_{12}-\mathrm{Ru}$, FITC, and RITC. The excitation and emission wavelengths used for following quantification were $\left(\operatorname{Ex}_{1}=430 \mathrm{~nm}, \mathrm{Em}_{1}=620 \mathrm{~nm}\right)$ for DBB-Ru, $\left(\operatorname{Ex}_{2}=465 \mathrm{~nm}, \mathrm{Em}_{2}=500 \mathrm{~nm}\right)$ for FITC, and $\left(\mathrm{Ex}_{3}=535 \mathrm{~nm}, \mathrm{Em}_{1}=600 \mathrm{~nm}\right)$ for RITC, for both free dye solutions and $\mathrm{Hf}_{12}-\mathrm{Ru}-\mathrm{F} / \mathrm{R}$ suspensions. 

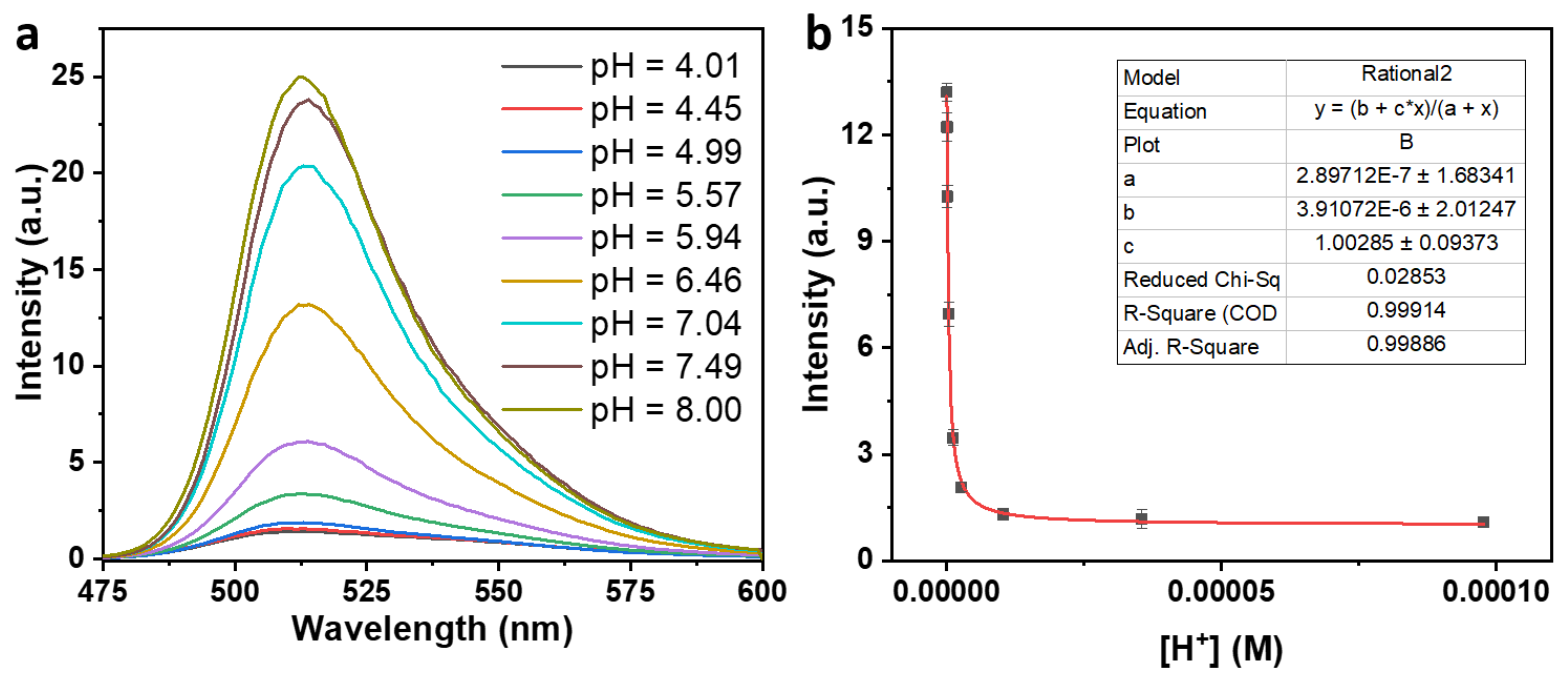

Figure S20. (a) emission spectra of $0.11 \mu \mathrm{M}$ free FITC in PBS at different $\mathrm{pH}$ values with excitation at $465 \mathrm{~nm}$ under normoxia. (b) Fitting of its luminescence intensity (Ex $=465 \mathrm{~nm}$, $\mathrm{Em}=500 \mathrm{~nm})$ against $\left[\mathrm{H}^{+}\right]$based on Eq. $\mathrm{S} 1$.
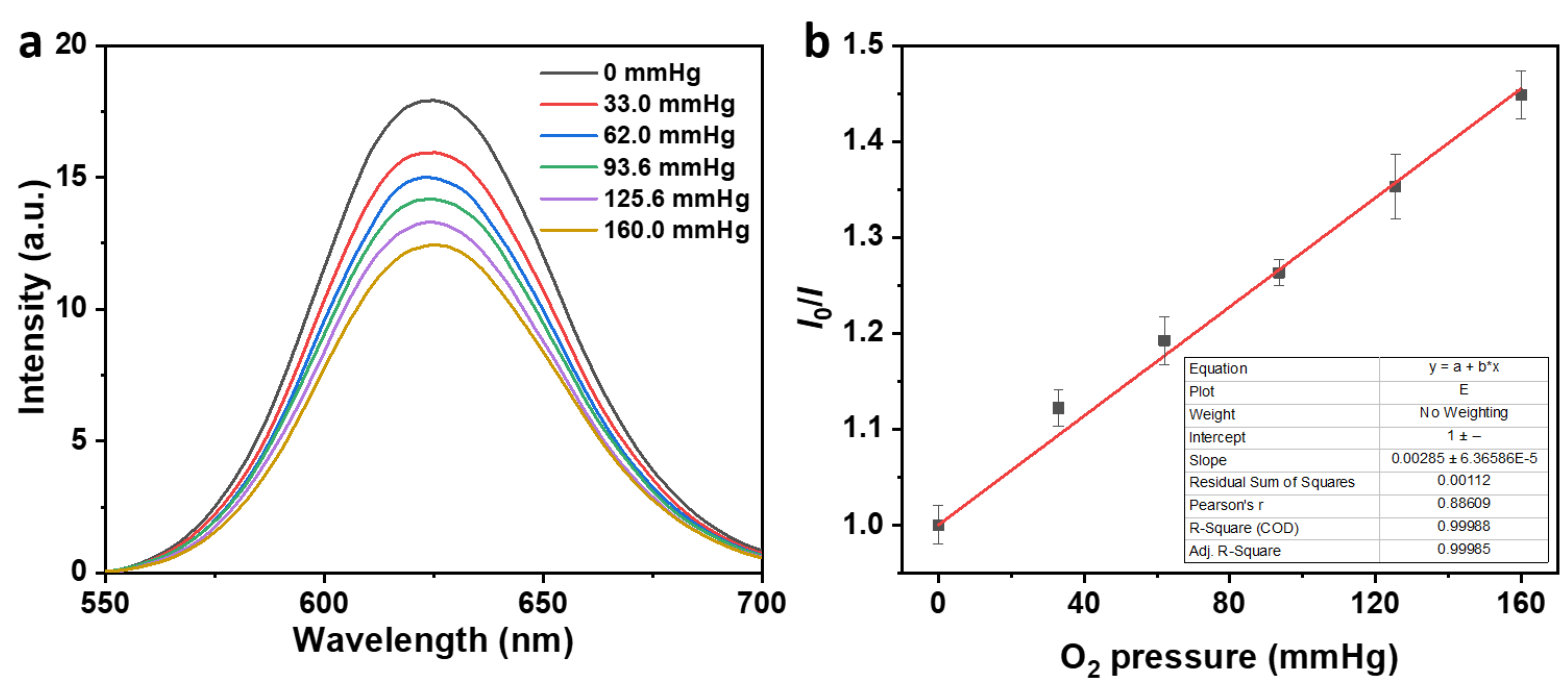

Figure S21. (a) Emission spectra of $10.0 \mu \mathrm{M}$ free $\mathrm{H}_{2} \mathrm{DBB}-\mathrm{Ru}$ in PBS ( $\mathrm{pH}=7.04$ ) under different $\mathrm{O}_{2}$ pressures with excitation at $430 \mathrm{~nm}$. (b) Fitting of its luminescence intensity ratio $I_{0} / I(E x=430 \mathrm{~nm}, \mathrm{Em}=620 \mathrm{~nm})$ against $\mathrm{O}_{2}$ pressure based on Eq. S5. 

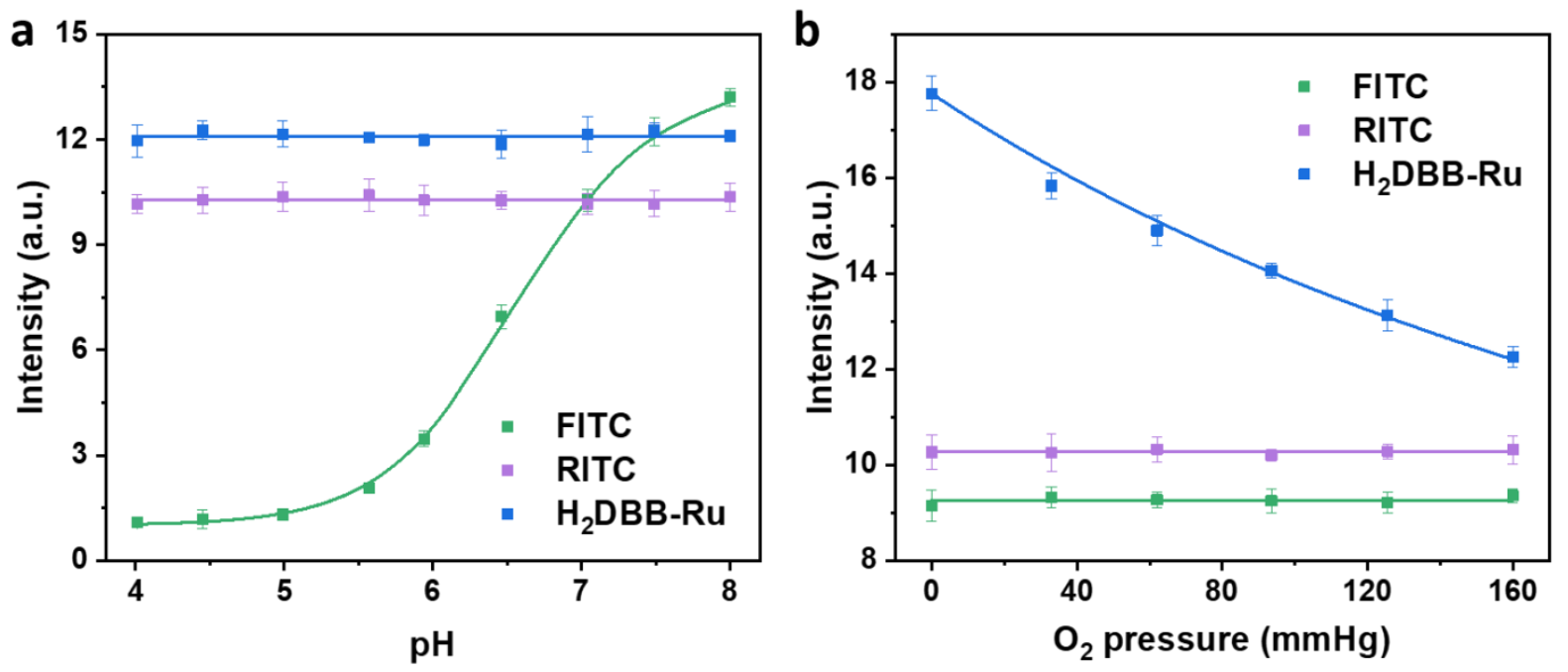

Figure S22. (a) Plots of luminescence intensities of $0.11 \mu \mathrm{M}$ free FITC, $0.56 \mu \mathrm{M}$ free RITC, and $10.0 \mu \mathrm{M}$ free $\mathrm{H}_{2} \mathrm{DBB}-\mathrm{Ru}$ at different $\mathrm{pHs}$ under normoxia. The luminescence intensity of FITC fitted well with Eq. S2, while the average intensities of RITC and $\mathrm{H}_{2} \mathrm{DBB}-\mathrm{Ru}$ were measured to be 10.27 and 12.09, respectively. (b) Plots of luminescence intensities of 0.11 $\mu \mathrm{M}$ free FITC, $0.56 \mu \mathrm{M}$ free RITC, and $10.0 \mu \mathrm{M}$ free $\mathrm{H}_{2} \mathrm{DBB}-\mathrm{Ru}$ in PBS ( $\mathrm{pH}=7.04$ ) under different $\mathrm{O}_{2}$ pressures. The luminescence intensity of $\mathrm{H}_{2} \mathrm{DBB}-\mathrm{Ru}$ fitted well with Eq. S6, while the average intensity of FITC and RITC was measured to be 9.26 and 10.28, respectively.
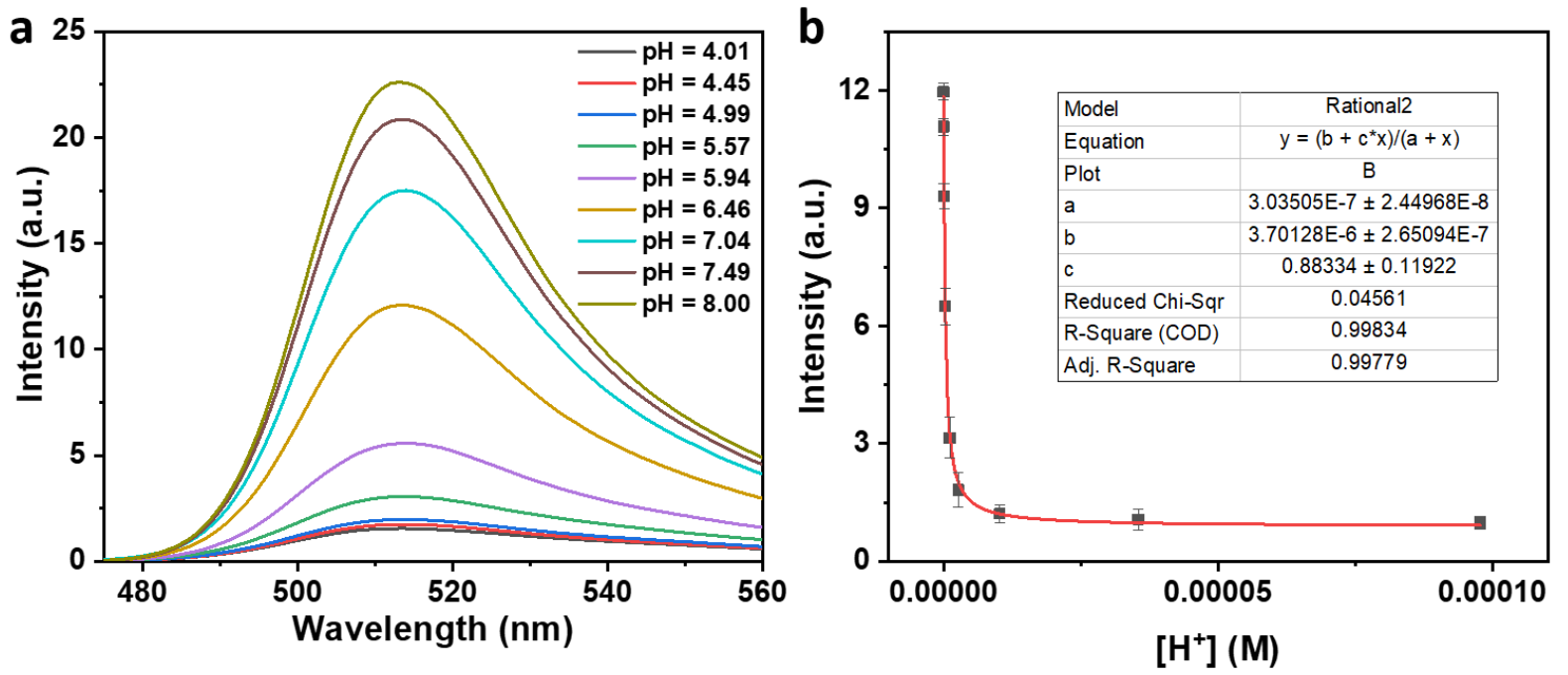

Figure S23. (a) emission spectra of $0.11 \mu \mathrm{M}$ FITC in $\mathrm{Hf}_{12}-\mathrm{Ru}-\mathrm{F} / \mathrm{R}$ suspensions in PBS at different $\mathrm{pH}$ with excitation at $465 \mathrm{~nm}$ under normoxia. (b) Fitting of its luminescence intensity $(\mathrm{Ex}=465 \mathrm{~nm}, \mathrm{Em}=500 \mathrm{~nm})$ against $\left[\mathrm{H}^{+}\right]$based on Eq. $\mathrm{S} 1$. 

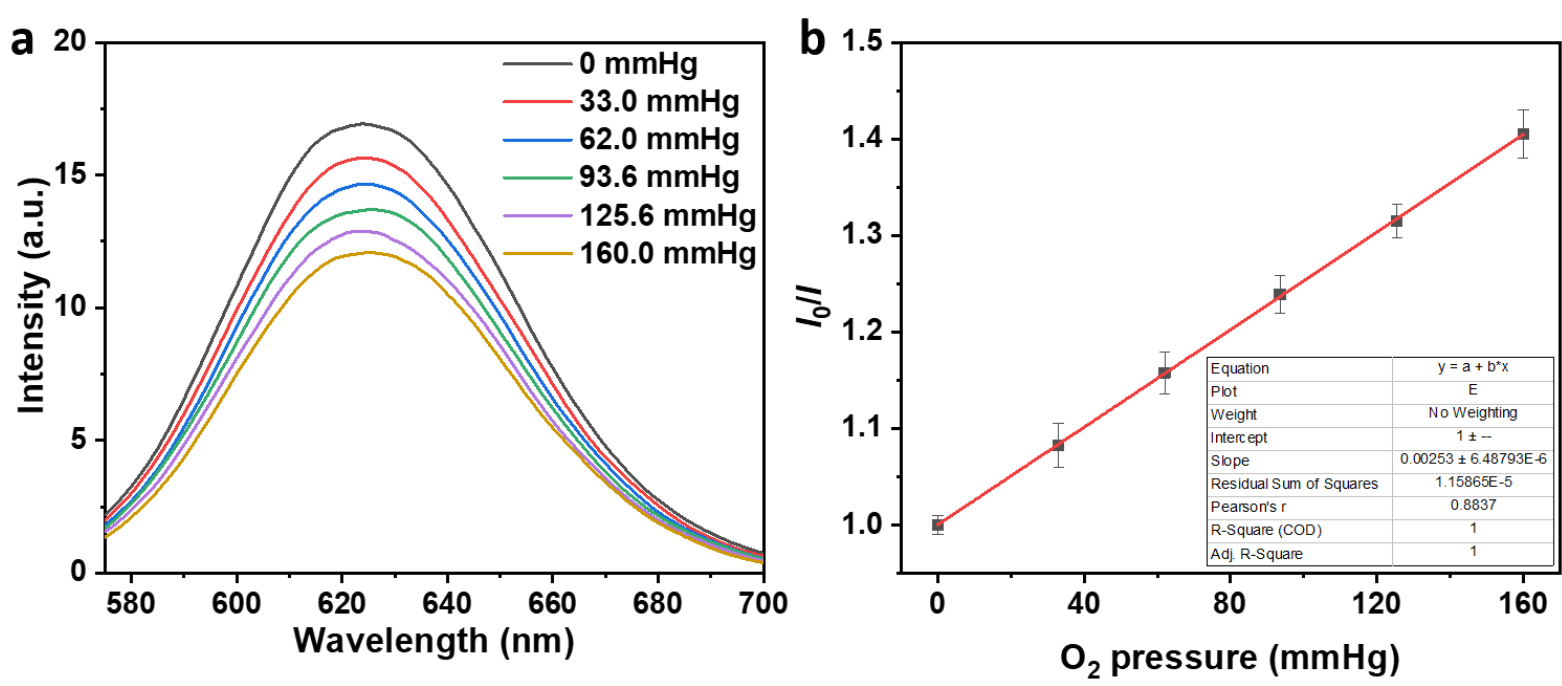

Figure S24. (a) Emission spectra of $10.0 \mu \mathrm{M}$ DBB-Ru in $\mathrm{Hf}_{12}-\mathrm{Ru}-\mathrm{F} / \mathrm{R}$ suspension in PBS $(\mathrm{pH}=7.04)$ under different $\mathrm{O}_{2}$ pressures with excitation at $430 \mathrm{~nm}$. (b) Fitting of its luminescence intensity ratio $I_{0} / I(E x=430 \mathrm{~nm}, \mathrm{Em}=620 \mathrm{~nm})$ against $\mathrm{O}_{2}$ pressure based on Eq. S5.
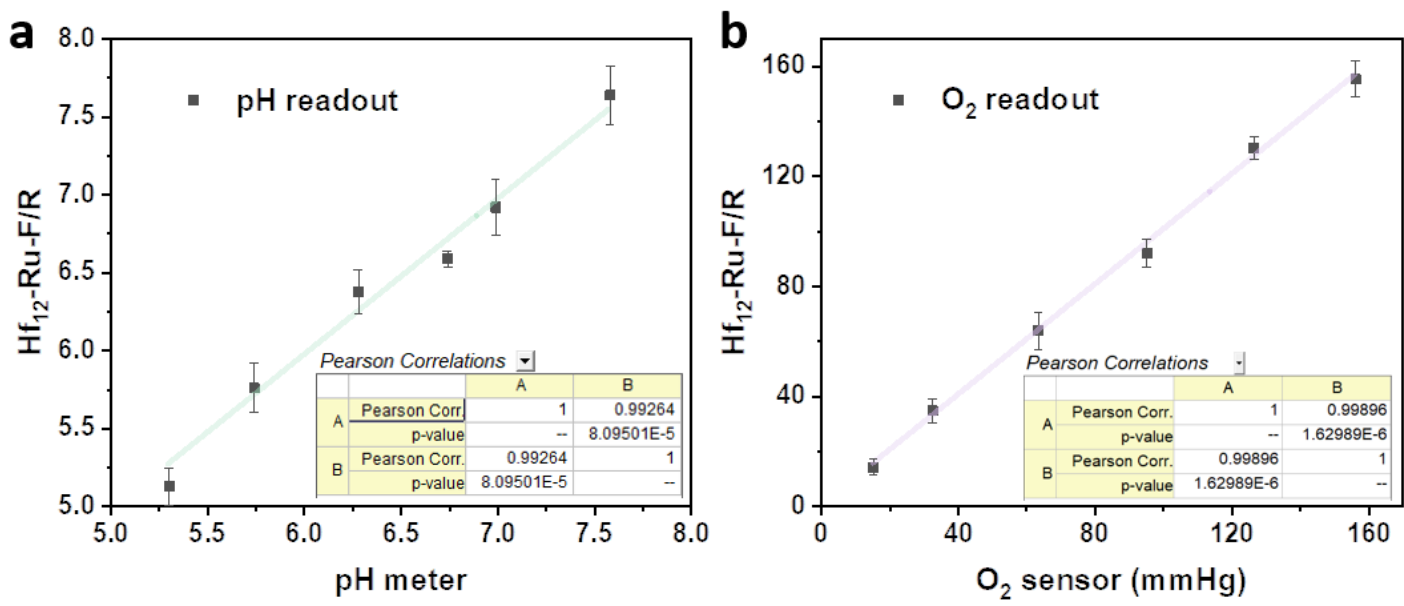

Figure S25. Validation of $\mathrm{Hf}_{12}-\mathrm{Ru}-\mathrm{F} / \mathrm{R}$ in $\mathrm{pH}$ (a) and $\mathrm{O}_{2}$ (b) sensing. $\mathrm{Hf}_{12}-\mathrm{Ru}-\mathrm{F} / \mathrm{R}$ showed $\mathrm{pH}$ and $\mathrm{O}_{2}$ readouts corresponding to those from a $\mathrm{pH}$ meter and an $\mathrm{O}_{2}$ sensor with Pearson correlation coefficients (r) of 0.992 and 0.999 , respectively. 


\section{S3.5 Standard curves as determined by Xenogen IVIS 200 imaging}

$\mathrm{Hf}_{12}-\mathrm{Ru}-\mathrm{F} / \mathrm{R}$ suspension $(\mathrm{DBB}-\mathrm{Ru}=10.0 \mu \mathrm{M}, \mathrm{FITC}=0.11 \mu \mathrm{M}$, and $\mathrm{RITC}=0.56 \mu \mathrm{M})$ in PBS with different $\mathrm{pH}(4.01,4.45,4.99,5.57,5.94,6.46,7.04,7.49$, and 8.00) was added to a 96-well plate with 6 wells for each $\mathrm{pH}$ point and $100 \mu \mathrm{L}$ of $\mathrm{Hf}_{12}-\mathrm{Ru}-\mathrm{F} / \mathrm{R}$ suspension for each well. These 96-well plates were then incubated in a glove box under different $\mathrm{O}_{2}$ pressure $(0$, 34.1, 63.5, 95.8, 124.2, and $160.0 \mathrm{mmHg}$ ). The luminescence signals of DBB-Ru, FITC, and RITC were collected with a Xenogen IVIS 200 imaging system with the excitation/emission parameter as shown in the Figure S19.
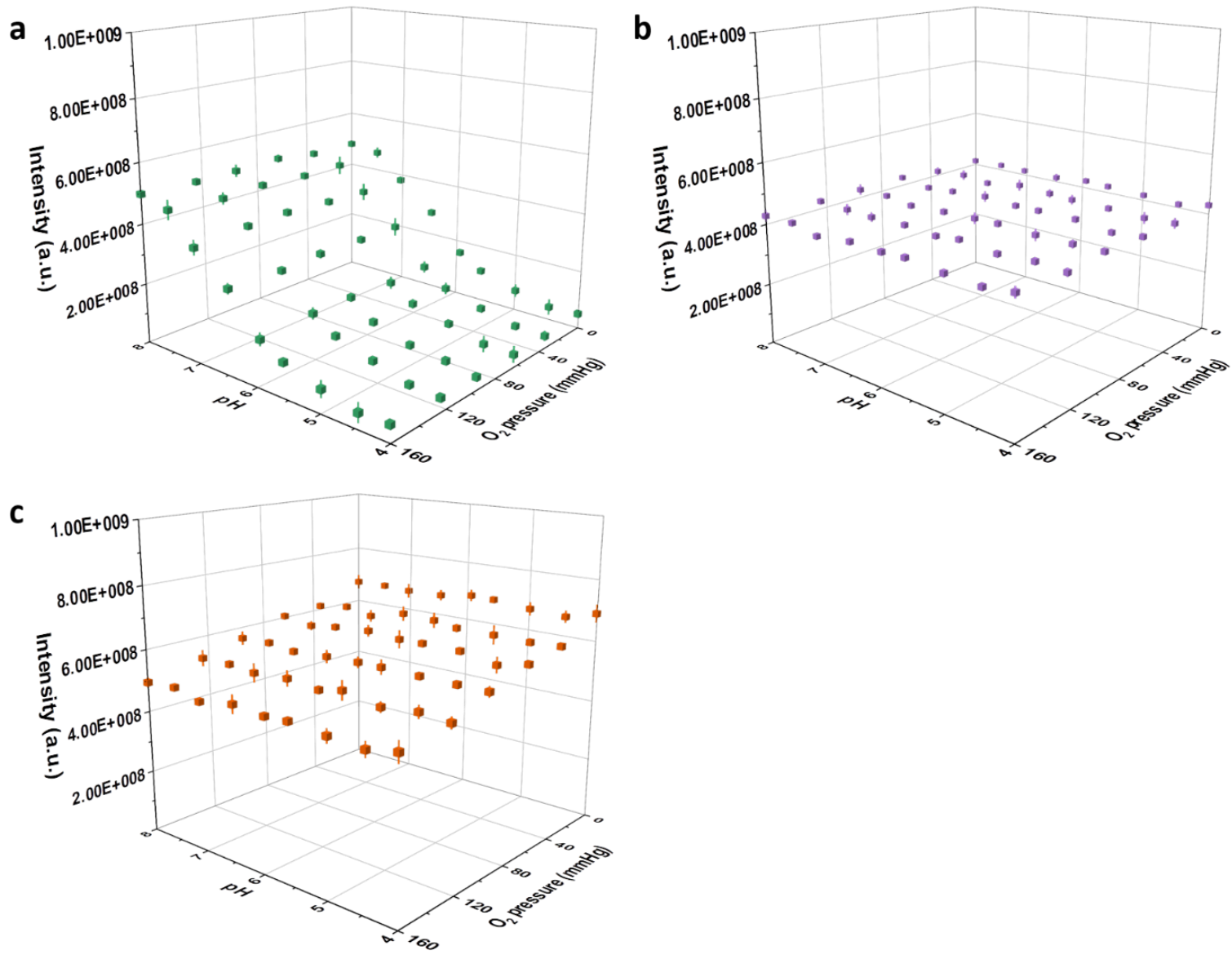

Figure S26. Plots of the luminescence intensities of FITC (a), RITC (b), and DBB-Ru (c) at different $\mathrm{pH}$ and $\mathrm{O}_{2}$ pressure as measured by a Xenogen IVIS 200 imaging system. 

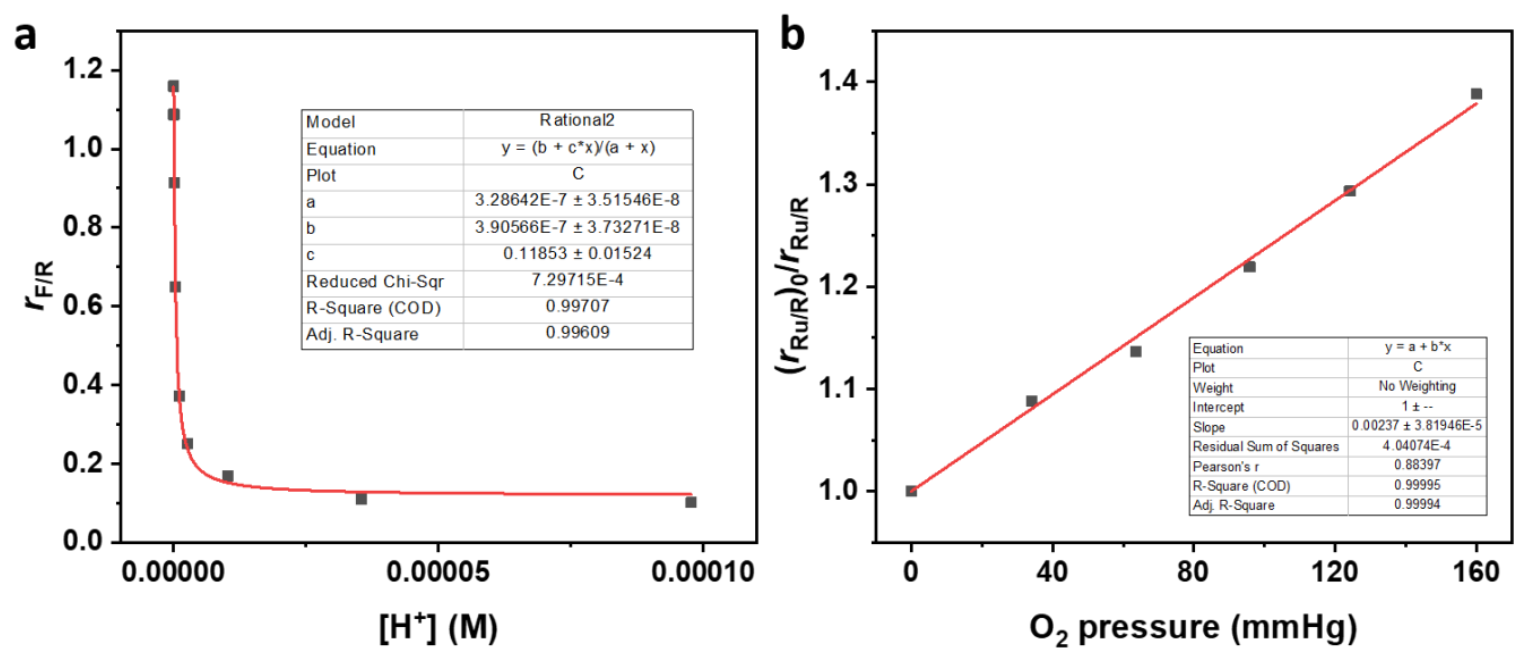

Figure S27. (a) Fitting of the luminescence intensity between FITC and RITC in $\mathrm{Hf}_{12}-\mathrm{Ru}-\mathrm{F} / \mathrm{R}$ suspension against $\left[\mathrm{H}^{+}\right]$based on Eq. S3. (b) Fitting of the luminescence intensity between DBB-Ru and RITC in $\mathrm{Hf}_{12}-\mathrm{Ru}-\mathrm{F} / \mathrm{R}$ suspension against $\mathrm{O}_{2}$ pressure based on Eq. S7.

\section{S4. In vitro $\mathrm{pH}$ and $\mathrm{O}_{2}$ sensing}

\section{S4.1 Cellular uptake of $\mathrm{Hf}_{12}-\mathrm{Ru}$ and $\mathrm{Hf}_{12}-\mathrm{Ru}-\mathrm{F} / \mathrm{R}$.}

The cellular uptakes of $\mathrm{Hf}_{12}-\mathrm{Ru}$ and $\mathrm{Hf}_{12}-\mathrm{Ru}-\mathrm{F} / \mathrm{R}$ were evaluated on CT26 cells. Cells were seeded on 6-well plates at $1.5 \times 10^{6} /$ well and further cultured overnight. Particles were added to the cells at a Hf concentration of $20 \mu \mathrm{M}$. After incubation of $0.5,2$ and 4 hours, the cells were collected, and the cell numbers were counted by a hemocytometer. Cells were digested with $1 \%$ hydrofluoric acid and concentrated nitric acid in a microwave reactor (CEM, USA) and the Hf concentrations were determined by ICP-MS (Agilent, USA). Results were expressed as the amount of Hf (ng) per $10^{5}$ cells. 


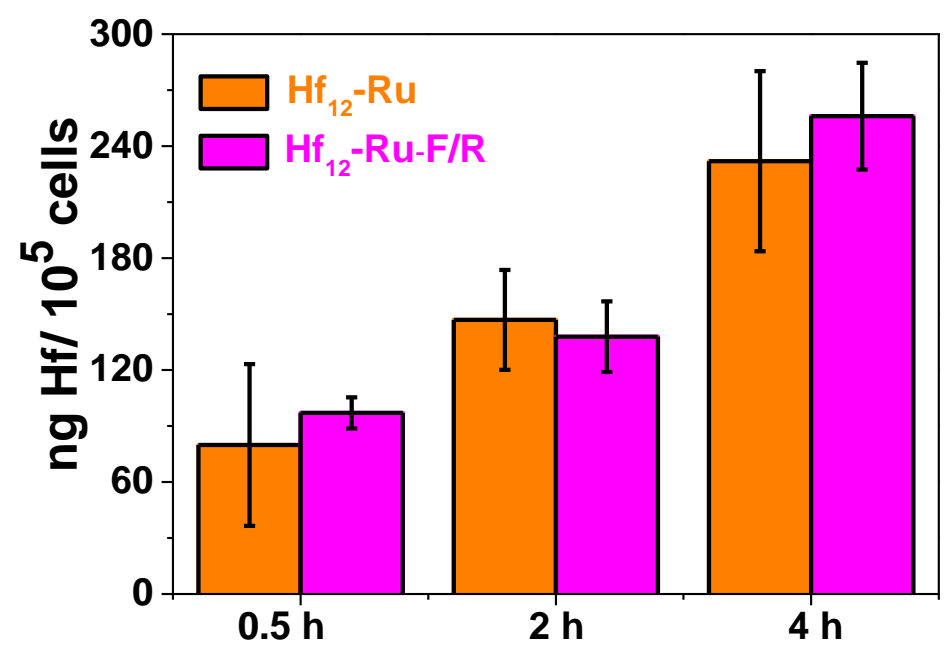

Figure S28. Cellular uptake of $\mathrm{Hf}_{12}-\mathrm{Ru}$ and $\mathrm{Hf}_{12}-\mathrm{Ru}-\mathrm{F} / \mathrm{R}$ after $0.5,2$ or $4 \mathrm{~h}$ incubation with equivalent $\mathrm{Hf}$ concentrations of $20 \mu \mathrm{M}(\mathrm{n}=3)$. The Hf concentrations were determined by ICP-MS.

\section{S4.2 Biosafety studies of $\mathrm{Hf}_{12}-\mathrm{Ru}$ and $\mathrm{Hf}_{12}-\mathrm{Ru}-\mathrm{F} / \mathrm{R}$.}

The cytotoxicity of $\mathrm{Hf}_{12}-\mathrm{Ru}$ and $\mathrm{Hf}_{12}-\mathrm{Ru}-\mathrm{F} / \mathrm{R}$ was evaluated with the 3-(4,5-dimethylthiazol-2-yl)-5-(3-carboxymethoxyphenyl)-2-(4-sulfo-phenyl)-2H-tetrazolium (MTS) assay (Promega, USA). CT26 or MC38 cells were seeded on 96-well plates at $2 \times 10^{5} /$ well and further cultured for $12 \mathrm{~h}$. $\mathrm{Hf}_{12}-\mathrm{Ru}$ or $\mathrm{Hf}_{12}-\mathrm{Ru}-\mathrm{F} / \mathrm{R}$ were added to the cells at an Hf-based dose of $0,0.1,0.2,0.51,2,5,10,20,50$ and $100 \mu \mathrm{M}$ and incubated for $72 \mathrm{~h}$ before determining the cell viability by MTS assay. 

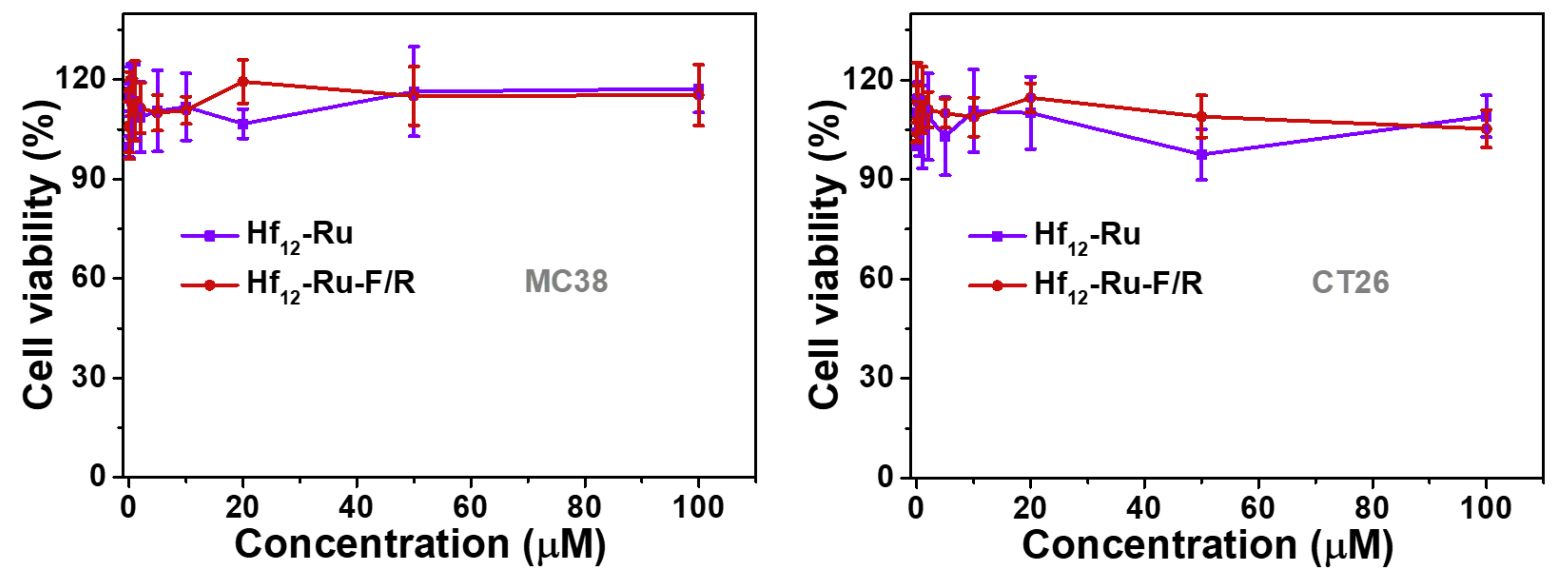

Figure S29. Cytotoxicity of $\mathrm{Hf}_{12}-\mathrm{Ru}$ and $\mathrm{Hf}_{12}-\mathrm{Ru}-\mathrm{F} / \mathrm{R}$ on $\mathrm{MC} 38$ and CT26. $\mathrm{n}=6$.

\section{S4.3 Colocalization of $\mathrm{Hf}_{12}-\mathrm{Ru}$ with MitoTracker.}

Mitochondria-targeting property of $\mathrm{Hf}_{12}-\mathrm{Ru}-\mathrm{F} / \mathrm{R}\left(\mathrm{Hf}_{12}-\mathrm{Ru}\right)$ was evaluated on CT26 cells. Cells were seeded on $35 \mathrm{~mm}$ glass bottom dishes (MatTek, USA) at $5 \times 10^{5} /$ well and further cultured overnight. Particles were added to the cells at a Hf concentration of $20 \mu \mathrm{M}$. MitoTracker $^{\mathrm{TM}}$ green was pre-loaded with a dilution of 1:2000 10 mins before the stop of particle incubation. 0.5, 2 and 4 hours post incubation, supernatant was removed and the dishes were transferred and cultured in hypoxic chamber for 30 mins. The samples were then rinsed with $1 \mathrm{~mL}$ PBS three times gently for directly scanning under SP8 LIGHTENING confocal microscope. Cells without particle incubation were used as control of incubation for $0 \mathrm{~h}$. Line pilot profiles and Pearson's coefficients were analyzed and calculated by ImageJ (NIH, USA) for colocalization.

To quantitatively analyze the mitochondria targeting property, extraction of mitochondria was conducted according to a previously reported protocol. ${ }^{3}$ CT26 cells were washed twice in mitochondrial extraction buffer containing mannitol $(200 \mathrm{mM})$, sucrose $(70 \mathrm{mM})$, HEPES $(10 \mathrm{mM})$, and EDTA $(1.0 \mathrm{mM})$ at $\mathrm{pH} 7.2$ and $4{ }^{\circ} \mathrm{C}$ and then re-suspended for homogenization. The homogenate was spun for $10 \mathrm{~min}$ at $600 \mathrm{~g}$ to recover the supernatant. The supernatant was further spun for $10 \mathrm{~min}$ at $11,000 \mathrm{~g}$ to recover the mitochondrial fraction for ICP-MS quantification. 


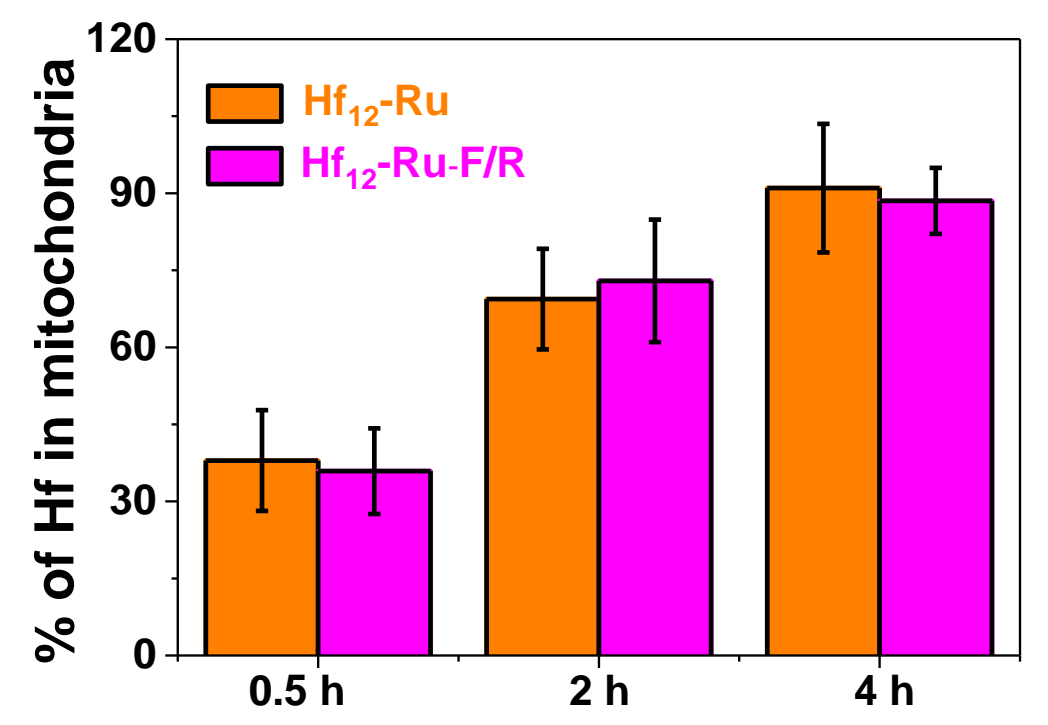

Figure S30. Time-dependent enrichment of $\mathrm{Hf}_{12}-\mathrm{Ru}$ or $\mathrm{Hf}_{12}-\mathrm{Ru}-\mathrm{F} / \mathrm{R}$ in mitochondria. Mitochondria were isolated from nMOL treated cells and the nMOL amounts quantified by ICP-MS. $\mathrm{n}=3$.
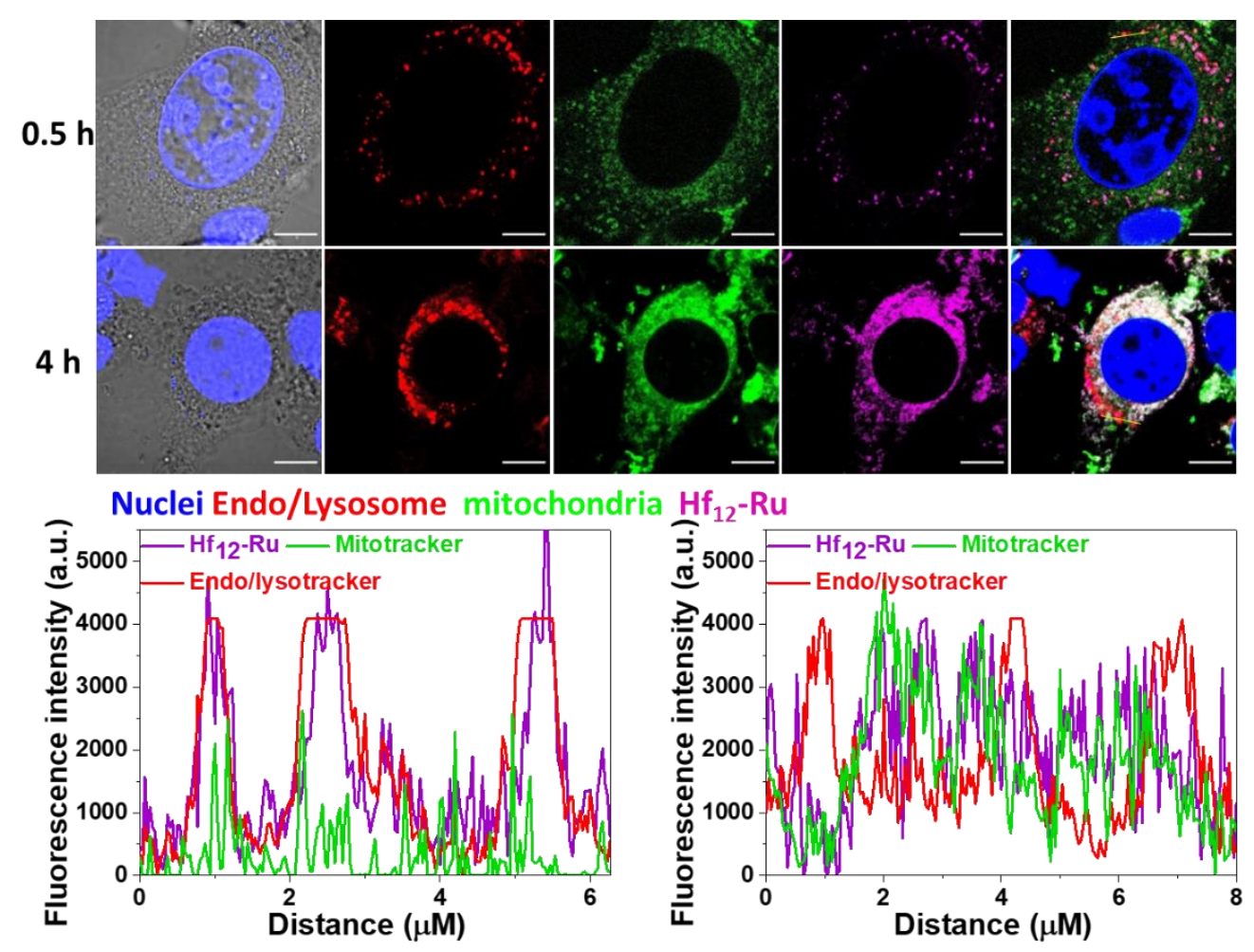

Figure S31. Corresponding line plot profiles at $0.5 \mathrm{~h}$ and $4 \mathrm{~h}$ post incubation of $\mathrm{Hf}_{12}-\mathrm{Ru}$. At $0.5 \mathrm{~h}$, Pearson's coefficients are 0.89 and 0.16 for Lysotracker/Hf $12-\mathrm{Ru}$ and 
Metotracker/Hf $12-\mathrm{Ru}$, respectively; at $4 \mathrm{~h}$, Pearson's coefficients are 0.45 and 0.91 for Lysotracker/Hf $12-\mathrm{Ru}$ and Metotracker/Hf $12-\mathrm{Ru}$, respectively.

\section{S4.4 $\mathrm{pH}$ and $\mathrm{O}_{2}$ sensing with $\mathrm{Hf}_{12}-\mathrm{Ru}-\mathrm{F} / \mathrm{R}$.}

CT26 cells were seeded on $35 \mathrm{~mm}$ glass bottom dishes (MatTek, USA) at $5 \times 10^{5} /$ well and further cultured overnight. Particles were added to the cells at a Hf concentration of $20 \mu \mathrm{M}$. After incubation for $4 \mathrm{~h}$, the supernatant was removed and the dishes were transferred and cultured under normoxic, hypoxic or anoxic conditions for 30 mins. The normoxic, hypoxic or anoxic conditions were achieved in glove box with the flowing of a mixture of $\mathrm{N}_{2}$ and Air (please see the procedure in S3.4). The samples were then rinsed with $1 \mathrm{~mL}$ PBS three times gently for directly scanning under SP8 LIGHTENING confocal microscope (Leica, Germany). Representative low-res and high-res confocal scanning laser microscopic (CLSM) images were harvested with $200 \times$ magnification or $400 \times$ magnification, respectively. Data to study the relation between $\mathrm{pH}$ and $\mathrm{O}_{2}$ were read from high-res CLSM images. 10 ROIs were randomly chosen from each figure and over 100 ROIs were analyzed for each condition. The imaging studies under normoxic condition were repeated to confirm the reproducibility.

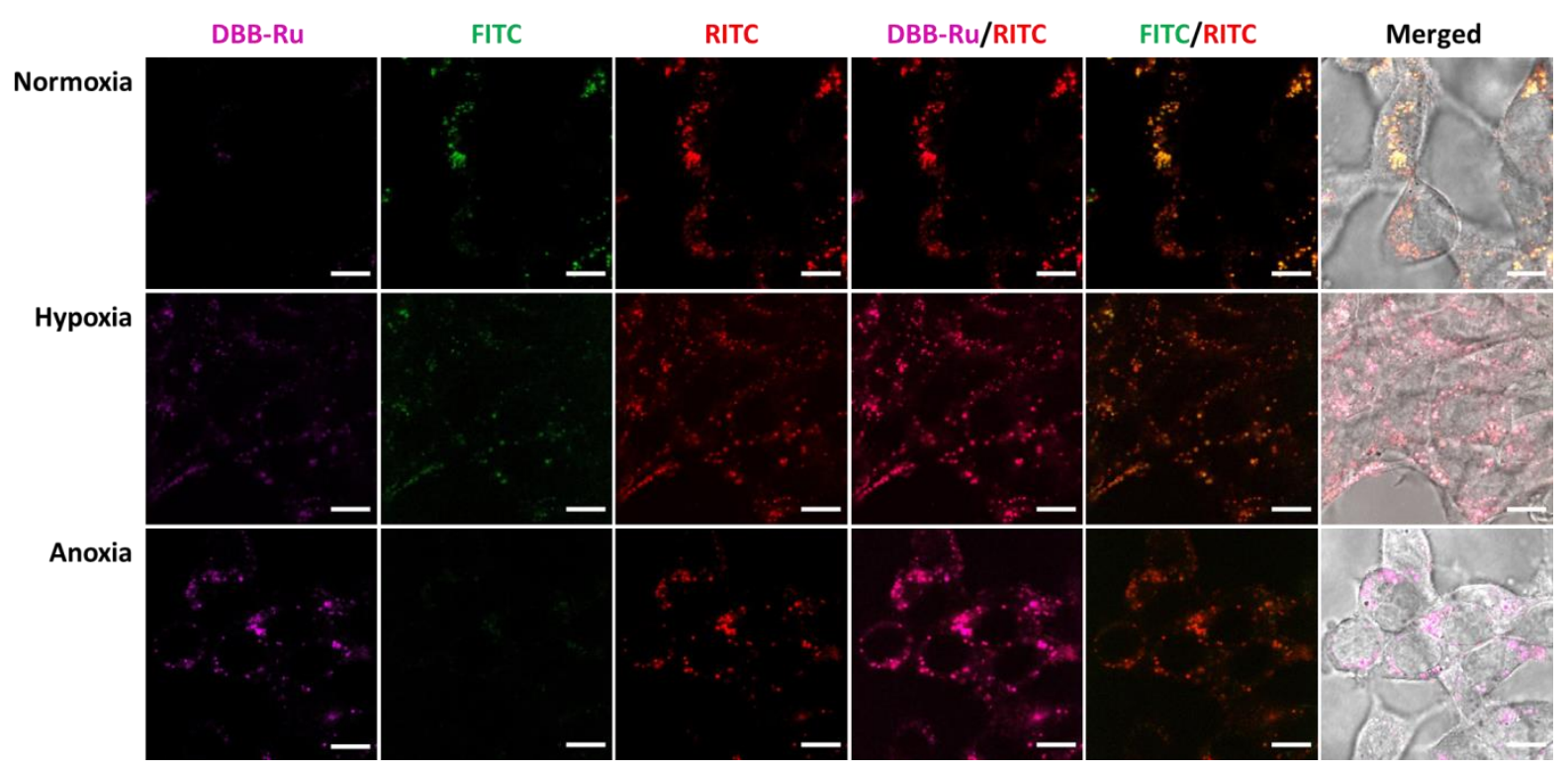

Figure S32. Representative low-res CLSM images showing luminescence intensities of DBB-Ru (magenta), FITC (green), and RITC (red) at different $\mathrm{O}_{2}$ pressures as sensed by $\mathrm{Hf}_{12}-\mathrm{Ru}-\mathrm{F} / \mathrm{R}$. Scale bar $=10 \mu \mathrm{m}$. 

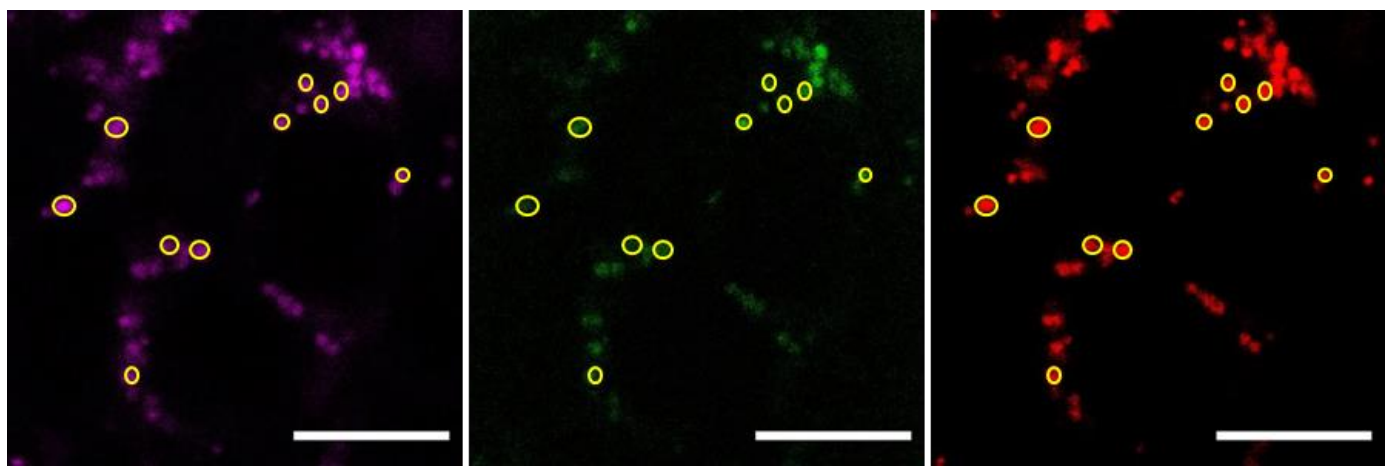

Figure S33. Representative case for randomly picked 10 ROIs on one set of high-res CLSM image. Scale bar $=10 \mu \mathrm{m}$.

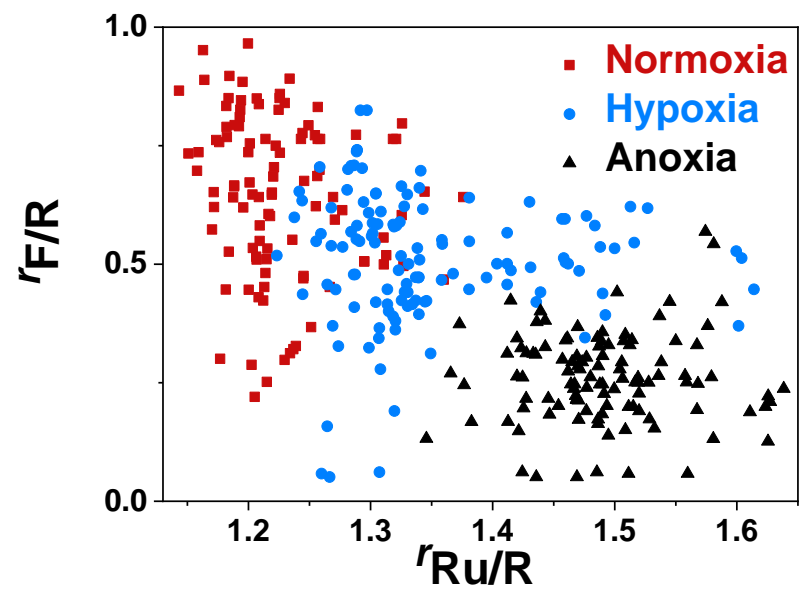

Figure S34. Data fitted from high-res CLSM images with standard curves in Figure S27.

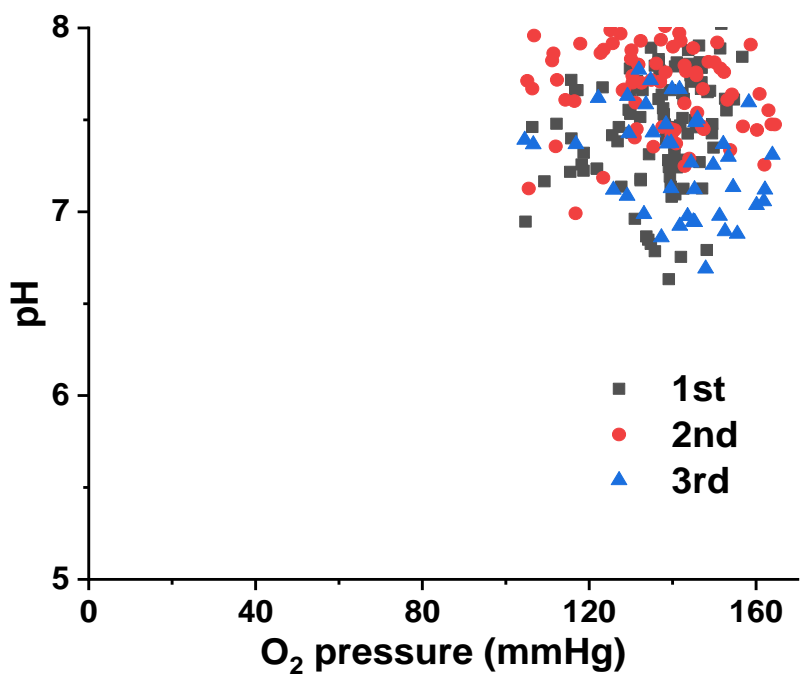

Figure S35. Data fitted from high-res CLSM images under normoxic condition for 3 separate 
experiments with standard curves in Figure S27, showing the reproducibility of $\mathrm{Hf}_{12}-\mathrm{Ru}-\mathrm{F} / \mathrm{R}$ sensing.

\section{S5. Reference}

1. Zhang, Z.-M.; Zhang, T.; Wang, C.; Lin, Z.; Long, L.-S.; Lin, W., Photosensitizing Metal-Organic Framework Enabling Visible-Light-Driven Proton Reduction by a Wells-Dawson-Type Polyoxometalate. J. Am. Chem. Soc. 2015, 137 (9), 3197-3200.

2. Martin, M. M.; Lindqvist, L., The pH dependence of fluorescein fluorescence. J. Lumin. 1975, 10 (6), 381-390

3. Ni, K.; Lan, G.; Veroneau, S. S.; Duan, X.; Song, Y.; Lin, W., Nanoscale metal-organic frameworks for mitochondria-targeted radiotherapy-radiodynamic therapy. Nat. Commun. 2018, 9 (1), 4321. 